\title{
Thermodynamic Impact of Mineral Surfaces on Amino Acid Polymerization: Aspartate Dimerization on Two-Line Ferrihydrite, Anatase, and $\gamma$-Alumina
}

\author{
Norio Kitadai ${ }^{1,2, *}$, Kumiko Nishiuchi ${ }^{2}$ and Wataru Takahagi ${ }^{1,3}$ (D) \\ 1 Super-cutting-edge Grand and Advanced Research (SUGAR) Program, Institute for Extra-cutting-edge \\ Science and Technology Avant-garde Research (X-star), Japan Agency for Marine-Earth Science and \\ Technology (JAMSTEC), Yokosuka 237-0061, Japan; watarut@g.ecc.u-tokyo.ac.jp \\ 2 Earth-Life Science Institute, Tokyo Institute of Technology, Tokyo 152-8550, Japan; nishiuchi_kumiko@elsi.jp \\ 3 Department of Chemistry, Graduate School of Science, The University of Tokyo, Tokyo 113-0033, Japan \\ * Correspondence: nkitadai@jamstec.go.jp
}

Citation: Kitadai, N.; Nishiuchi, K.; Takahagi, W. Thermodynamic Impact of Mineral Surfaces on Amino Acid Polymerization: Aspartate Dimerization on Two-Line Ferrihydrite, Anatase, and $\gamma$-Alumina. Minerals 2021, 11, 234. https://doi.org/10.3390/min11030234

Academic Editor: Huifang Xu

Received: 15 January 2021

Accepted: 22 February 2021

Published: 25 February 2021

Publisher's Note: MDPI stays neutral with regard to jurisdictional claims in published maps and institutional affiliations.

Copyright: (c) 2021 by the authors. Licensee MDPI, Basel, Switzerland. This article is an open access article distributed under the terms and conditions of the Creative Commons Attribution (CC BY) license (https:// creativecommons.org/licenses/by/ $4.0 /)$.

\begin{abstract}
The presence of amino acids in diverse extraterrestrial materials has suggested that amino acids are widespread in our solar system, serving as a common class of components for the chemical evolution of life. However, there are a limited number of parameters available for modeling amino acid polymerization at mineral-water interfaces, although the interfacial conditions inevitably exist on astronomical bodies with surface liquid water. Here, we present a set of extended triple-layer model parameters for aspartate (Asp) and aspartyl-aspartate (AspAsp) adsorptions on two-line ferrihydrite, anatase, and $\gamma$-alumina determined based on the experimental adsorption data. By combining the parameters with the reported thermodynamic constants for amino acid polymerization in water, we computationally demonstrate how these minerals impact the AspAsp/Asp equilibrium over a wide range of environmental conditions. It was predicted, for example, that two-line ferrihydrite strongly promotes Asp dimerization, leading to the AspAsp/Asp ratio in the adsorbed state up to $41 \%$ even from a low Asp concentration $(0.1 \mathrm{mM})$ at $\mathrm{pH}$, which is approximately $5 \times 10^{7}$ times higher than that attainable without mineral $\left(8.5 \times 10^{-6 \%}\right)$. Our exemplified approach enables us to screen wide environmental settings for abiotic peptide synthesis from a thermodynamic perspective, thereby narrowing down the geochemical situations to be explored for life's origin on Earth and Earth-like habitable bodies.
\end{abstract}

Keywords: adsorption; astrobiology; chemical evolution; origin of life; polymerization; surface complexation modeling

\section{Introduction}

Following the discoveries of thousands of exoplanetary systems [1,2], a significant effort is being devoted to the laboratory simulation of the formation and oligomerization of biologically relevant compounds on a planetary surface, thereby evaluating the possibility and architecture of life to exist [3-5]. Amino acids are frequently targeted compounds for several reasons: (1) they are major building blocks for Earth's life, (2) they have been synthesized in numerous experiments simulating primordial geochemical events [6], (3) they are representative soluble organic matter in extraterrestrial materials (carbonaceous chondrites and comets) $[7,8]$, and (4) they facilitate various organic/inorganic reactions possibly crucial to life's origin $[9,10]$. Thus, the availability and versatility in prebiotic chemistry not limited to Earth suggest that amino acids are a major class of components for the extraterrestrial as well as the terrestrial origins of life.

At the mineral-water interface, amino acids exhibit considerably different polymerization reactivities from those in aqueous solution [11,12]. Although this phenomenon has long been studied in the prebiotic chemistry context, its parameterization for geo- and astrochemical modeling applications remains limited. A limitation of this parameterization 
is the kinetic difficulty in controlling the amino acid polymerization rate within experimentally monitorable levels while suppressing other undesirable reactions. To accelerate the polymerization, experiments have typically been conducted at elevated temperatures (e.g., $200{ }^{\circ} \mathrm{C}$ ) with high concentrations of amino acids (e.g., $100 \mathrm{mM}$ ) [13]. However, the extrapolation of the results to those at naturally prevalent conditions, $0-50{ }^{\circ} \mathrm{C}$ for the early Archean ocean [14], is always difficult owing to the occurrence of side reactions (e.g., decomposition) and the kinetic complexity of mineral-water-solute interactions [15].

Thermodynamics provides a way to circumvent this problem. The equilibrium constant for amino acid polymerization on a mineral is expressed by combining the surface adsorption constants of the amino acid and its peptide with the polymerization constant in water (Figure 1a). Amino acids and peptides readily attain adsorption equilibria at ambient temperature, and the thermodynamic data of these dissolved species are available in the literature [16-18]. Thus, by experimentally obtaining the adsorption data as a function of reaction conditions and formulating a surface complexation model based on the results, the thermodynamically attainable peptide concentration on the mineral is computable over a wide range of environmental conditions.

We recently applied this methodology to L-aspartate (Asp)-goethite and L-lysine (Lys)amorphous-silica systems $[19,20]$. In both systems, the adsorption was largely controlled by the electrostatic amino acid-surface interaction, resulting in the prediction that goethite promotes Asp dimerization at slightly acidic $\mathrm{pH}(4-5)$, while amorphous silica promotes Lys dimerization at slightly alkaline $\mathrm{pH}(\sim 9)$. Since the goethite-Asp (or AspAsp) binding, which involved outer- and inner-sphere complexes [20], was stronger than the outer-sphere amorphous-silica-Lys (or LysLys) binding [19,21], the former system exhibited a greater increase in equilibrium dipeptide concentration, up to $\sim 10^{5}$-fold enhancement of $0.1 \mathrm{mM}$ Asp dimerization by $10 \mathrm{~m}^{2} \cdot \mathrm{L}^{-1}$ goethite. Importantly, in the absence of minerals, Asp and Lys have similar $\mathrm{pH}$ dependence of dipeptide concentration at equilibrium [22]. Thus, our calculation indicated that the mineral-water interfacial condition is a crucial factor for the sequence and yield of the peptides producible abiotically.

In this study, we aim to expand the computable mineral-amino acid combinations for screening wider and diverse environmental settings for abiotic peptide formation. Given the promising role of goethite in Asp dimerization introduced above [20], we examined the influence of two-line ferrihydrite (hereafter, we simply call it ferrihydrite), anatase, and $\gamma$-alumina on the AspAsp/Asp equilibrium. Ferrihydrite is a low-crystalline iron oxide precursor of goethite and hematite [23] possibly widespread even on the anoxic primordial Earth owing to the photochemical oxidation of siderite to Fe(III) minerals [24]. Anatase and $\gamma$-alumina are oxides of titanium and aluminum, respectively, which are common metal components on the Earth's crust. Although silica is also prevalent on the Earth surface, no adsorption of Asp and AspAsp was observed (data not shown), indicating the negligible influence of silica on Asp dimerization thermodynamics. It should be noted that there are numerous experimental data for amino acid and peptide adsorption in the literature [25]. However, in many cases, particularly for peptides, their reaction condition dependencies are not examined sufficiently for modeling amino acid polymerization in a wide range of environmental conditions (e.g., as a function of $\mathrm{pH}$, electrolyte concentrations, amino acid concentration, and the solid/water ratio). To the best of our knowledge, the thermodynamic datasets available for such purposes are given by our previous studies alone $[19,20]$. 
(a) $\log \mathrm{K}_{(\mathrm{A})}$ $=\log \mathrm{K}_{(\mathrm{B})}-\log \mathrm{K}_{(\mathrm{C})}+\log \mathrm{K}_{(\mathrm{D})}$

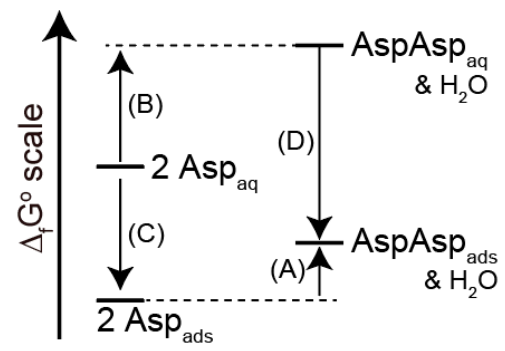

(b) Asp $_{\text {ads }}$

$=(>\mathrm{MO})_{2} \mathrm{Asp} \&\left(>\mathrm{MOH}_{2}{ }^{+}\right)_{2} \mathrm{Asp}^{-}$ (c) AspAsp ${ }_{\text {ads }}$ $=\left(>\mathrm{MO}_{2}\right)_{2} \mathrm{AspAsp}^{-} \&(>\mathrm{MO})_{2} \mathrm{AspAsp}$

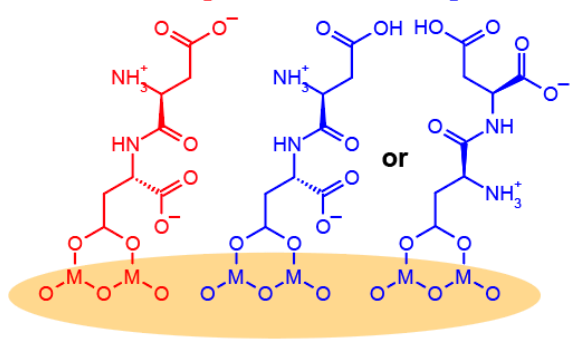

Figure 1. (a) Schematic showing the thermodynamic relationships among (b) the dimerization of adsorbed Asp (Aspads), (b) dimerization of dissolved Asp (Aspaq), (c) adsorption of Aspaq, and (D) adsorption of AspAspaq. The Asp and AspAsp surface species assumed in this study are depicted in (b) and (c), respectively.

\section{Materials and Methods}

\subsection{Materials}

Asp and AspAsp were purchased from Peptide Institute (Catalog No. 2704) and BACHEM (Catalog No. G-1565), respectively. Anatase was obtained from EM Japan (Catalog No.: NP-TIO2-4; 99.98\% purity). $\gamma$-alumina was provided by Sumitomo Chemical (Catalog No.: AKP-G15; $\geq 99.99 \%$ purity). Ferrihydrite was prepared following a previously reported procedure [26,27]. $\mathrm{To} \mathrm{FeCl}_{3}$ aqueous solution (typically $10 \mathrm{mM}$ ), 0.1 or $1 \mathrm{M} \mathrm{NaOH}$ was added in a dropwise manner until the $\mathrm{pH}$ reached 8.0 in a glove box filled with $\mathrm{N}_{2}$ gas ( $>99.99995 \%$ purity) at room temperature $\left(25^{\circ} \mathrm{C} \pm 2{ }^{\circ} \mathrm{C}\right)$. The resultant suspension was aged over $3 \mathrm{~h}$ under vigorous stirring at $\mathrm{pH}$ 8.0, and it was diluted to certain concentrations for use in adsorption experiments. No crystalline impurity was detected by $\mathrm{X}$-ray diffraction (XRD) analysis (Figure A1). The specific surface area and the average pore diameter were $408 \mathrm{~m}^{2} \cdot \mathrm{g}^{-1}$ and $2.3 \mathrm{~nm}$ for ferrihydrite, $50 \pm 0.7 \mathrm{~m}^{2} \cdot \mathrm{g}^{-1}$ and $23 \mathrm{~nm}$ for anatase [28], and $164 \mathrm{~m}^{2} \cdot \mathrm{g}^{-1}$ and 33nm for $\gamma$-alumina, respectively (Figures A2 and A3). Since the dried ferrihydrite has lower specific surface area than that dispersed in water because of the particle aggregation [29], we set the ferrihydrite surface area to $600 \mathrm{~m}^{2} \cdot \mathrm{g}^{-1}[26,27]$ in the adsorption data analysis described below. The solid/water ratio of ferrihydrite was calculated using the reported ferrihydrite chemical formula of $\mathrm{Fe}_{10} \mathrm{O}_{14}(\mathrm{OH})_{2}$ [30]. Milli-Q water (18.2 megohms) was used as the solvent for all the aqueous solutions. $\mathrm{pH}$ and temperature were monitored with a portable $\mathrm{pH}$ meter (Seven2Go Pro; Mettler Toledo, Zürich, Switzerland).

\subsection{Adsorption Experiments}

All adsorption experiments were conducted in a glove box filled with $\mathrm{N}_{2}$ gas at $25{ }^{\circ} \mathrm{C}$ $\pm 2{ }^{\circ} \mathrm{C}$. The initial Asp and AspAsp concentrations were set to 0.1 or $0.5 \mathrm{mM}$, and 10 or $100 \mathrm{mM} \mathrm{NaCl}$ was used as the background electrolyte. The solid/water ratios were 2.5 or $5 \mathrm{~g} \cdot \mathrm{L}^{-1}$ for anatase and $\gamma$-alumina, and 0.136 or $0.27 \mathrm{~g} \cdot \mathrm{L}^{-1}$ for ferrihydrite. The $\mathrm{pH}$ of the anatase and ferrihydrite suspensions was adjusted between 3 and 10 with regent grade $\mathrm{HCl}$ or $\mathrm{NaOH}$, whereas the $\mathrm{pH}$ range was limited to $5-10$ for $\gamma$-alumina because of the rapid dissolution at acidic $\mathrm{pH}$ [31]. All the sample suspensions ( $4 \mathrm{~mL}$ for each) were prepared in a $15 \mathrm{~mL}$ polypropylene centrifuge tube and rotated at $25 \mathrm{rpm}$ for $20 \mathrm{~h}$ to adequately attain the adsorption equilibria. Afterwards, the samples were measured for $\mathrm{pH}$, centrifuged at $8000 \mathrm{rpm}$ for $10 \mathrm{~min}$, and filtered with a polytetrafluoroethylene membrane filter.

The Asp and AspAsp remaining in the filtrates were quantified by a high-performance liquid chromatograph (HPLC) equipped with a postcolumn derivatization system with o-phthalaldehyde (JASCO HPLC system, Tokyo, Japan). A fluorescence detector was operated at $345 \mathrm{~nm}$ and $455 \mathrm{~nm}$ for excitation and emission, respectively. Five citrate buffer solutions with different citrate concentrations and $\mathrm{pH}$ were used as eluents in a stepwise manner. A cation-exchange column (AApak Na II-S2; JASCO) was used at $50^{\circ} \mathrm{C}$. To ensure 
reproducibility, we performed multiple independent runs under several sets of reaction conditions. The differences among the data obtained under identical conditions were less than $10 \%$.

In the AspAsp samples, small amounts of Asp were observed because of the peptidebond hydrolysis during the adsorption experiment. In most cases, the Asp concentrations were less than $0.5 \%$ of the initial AspAsp concentration, but relatively high values up to $1.5 \%$ were measured, particularly when a high solid/AspAsp ratio was examined (e.g., $5 \mathrm{~g} \cdot \mathrm{L}^{-1}$ anatase mixed with $0.1 \mathrm{mM}$ AspAsp). AspAsp hydrolysis could be greater than those expected from the quantified Asp concentrations because of Asp adsorption. However, we did not consider the hydrolysis in the data analysis described below because the resultant overestimations of AspAsp adsorption were likely still insignificant compared to the uncertainties arising from the experimental reproducibility.

\subsection{Thermodynamic Calculation}

All computations were performed with the extended triple-layer model (ETLM), a triple-layer model that consider the electrostatics of water dipole desorption during the ligand exchange reaction [32,33]. ETLM differs from TLM only in the electrostatic term associated with inner-sphere adsorption, and it involves no additional fitting parameters. Thus, ETLM can be used in any geochemical modeling programs including TLM, such as GEOSURF [34], MINTEQL+ [35], PHREEQC [36], and visual-MINTEQ [37]. In this study, we used visual-MINTEQ. The protonation constants of Asp and AspAsp were set to the values reported in the NIST database [38] and literature [39], respectively (Table A1). The dissociation constants of dissolved $\mathrm{NaOH}, \mathrm{NaCl}$, and $\mathrm{HCl}$ were taken from [40,41], and [42], respectively. The aqueous complexes between organic species and inorganic ions were not considered because of the lack of thermodynamic parameters for AspAsp. The mole fraction of the Asp forming complex with $\mathrm{Na}^{+}\left(\mathrm{Asp}^{2-}+\mathrm{Na}^{+} \rightarrow \mathrm{Asp}^{2-}{ }_{-} \mathrm{Na}^{+}\right)$, which is calculable with the reported constant $(\log \mathrm{K}=0.08$ [38]), is at most $5 \%$ in the examined aqueous condition. This small fraction had no appreciable influence on the ETLM regression calculation of the experimental adsorption data (data not shown). The same should be true for AspAsp.

\section{Results and Discussion}

\subsection{ETLM Analysis of the Experimental Adsorption Data}

The ETLM calculation for solute-surface interaction requires parameters for surface species and surface charge properties in an aqueous solution. Specifically, it requires the specific surface area $\left(\mathrm{A}_{\mathrm{s}}\right)$, surface site density $\left(\mathrm{N}_{\mathrm{s}}\right)$, inner- and outer-layer capacitances ( $C_{1}$ and $C_{2}$; we here set $C_{1}=C_{2}$ in all calculations [24]), surface protonation constants $\left(\mathrm{K}_{1}\right.$ and $\left.\mathrm{K}_{2}\right)$, electrolyte adsorption constants $\left(\mathrm{K}_{\mathrm{Na}+}\right.$ and $\left.\mathrm{K}_{\mathrm{Cl}-}\right)$, and, in our case, Asp and AspAsp adsorption constants. We set the values of $\mathrm{N}_{\mathrm{s}}, \mathrm{C}_{1}\left(=\mathrm{C}_{2}\right), \mathrm{K}_{1}, \mathrm{~K}_{2}, \mathrm{~K}_{\mathrm{Na}+}$, and $\mathrm{K}_{\mathrm{Cl}-\text { for }}$ ferrihydrite to those reported in ref. [27] (Tables 1 and A2). For $\gamma$-alumina, the values of $\mathrm{N}_{\mathrm{s}}$

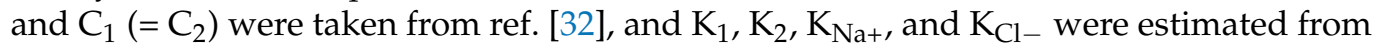
the ETLM fitting of the $\gamma$-alumina surface charge data (Figure A4a). Similarly, the values of $\mathrm{N}_{\mathrm{s}}$ and $\mathrm{C}_{1}\left(=\mathrm{C}_{2}\right)$ for anatase were obtained from refs. [43] and [32], respectively, and $\mathrm{K}_{1}$,

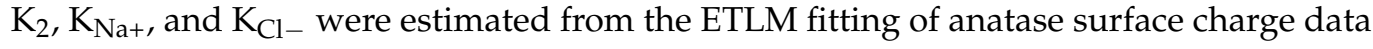
(Figure A4b).

The Asp and AspAsp adsorption constants should be determined with stoichiometries consistent with the actual surface binding modes. However, even Asp adsorption remains controversial in spectroscopic and computational investigations (Table A3). The proposed functional groups crucial for Asp binding on $\mathrm{TiO}_{2}$, for example, includes the amino group $\left(\mathrm{NH}_{3}{ }^{+}\right.$or $\left.\mathrm{NH}_{2}\right)$ [44,45], side chain methylene group [46], and either or both of the $\alpha-\mathrm{COO}^{-}$ and $\beta-\mathrm{COO}^{-}$groups [47-51]. These disagreements probably indicate the difficulty in determining the Asp interfacial structure rather than reflect the difference in the examined $\mathrm{TiO}_{2}$ surface environments [52]. 
Table 1. Stoichiometries, electrostatic factors, and equilibrium constants for the solute-surface interactions on ferrihydrite, anatase, and $\gamma$-alumina considered in this study.

\begin{tabular}{|c|c|c|c|c|}
\hline \multirow{2}{*}{ Reaction } & \multirow{2}{*}{$\Psi 1$} & \multicolumn{3}{|c|}{$\log \mathrm{K}^{\mathrm{MF} 2}$} \\
\hline & & Ferrihydrite & Anatase & $\gamma$-Alumina \\
\hline$>\mathrm{MOH}+\mathrm{H}^{+} \rightarrow>\mathrm{MOH}_{2}{ }^{+}$ & $\psi_{0}$ & 3.7 & 3.1 & 4.2 \\
\hline$>\mathrm{MOH} \rightarrow>\mathrm{MO}^{-}+\mathrm{H}^{+}$ & $-\psi_{0}$ & -12.1 & -9.9 & -12.3 \\
\hline$>\mathrm{MOH}+\mathrm{Na}^{+} \rightarrow>\mathrm{MO}^{-}{ }_{-} \mathrm{Na}^{+}+\mathrm{H}^{+}$ & $-\psi_{0}+\psi_{\beta}$ & -8.2 & -7.1 & -8.4 \\
\hline$>\mathrm{MOH}+\mathrm{Cl}^{-}+\mathrm{H}^{+} \rightarrow>\mathrm{MOH}_{2}^{+}{ }_{-} \mathrm{Cl}^{+}+\mathrm{H}^{+}$ & $\psi_{0}-\psi_{\beta}$ & 8.1 & 5.9 & 7.9 \\
\hline $2>\mathrm{MOH}+\mathrm{Asp}^{2-}+2 \mathrm{H}^{+} \rightarrow(>\mathrm{MO})_{2} \mathrm{Asp}+2 \mathrm{H}_{2} \mathrm{O}$ & - & 18.2 & 17.2 & 17.6 \\
\hline $2>\mathrm{MOH}+\mathrm{Asp}^{2-}+3 \mathrm{H}^{+} \rightarrow\left(>\mathrm{MOH}_{2}^{+}\right)_{2} \mathrm{Asp}^{-}$ & $2 \psi_{0}-\psi_{\beta}$ & 30.2 & 26.5 & 27.7 \\
\hline $2>\mathrm{MOH}+\mathrm{AspAsp}^{3-}+2 \mathrm{H}^{+} \rightarrow(>\mathrm{MO})_{2} \mathrm{AspAsp}^{-}+2 \mathrm{H}_{2} \mathrm{O}$ & $-\psi_{\beta}$ & 21.2 & 19.0 & 19.5 \\
\hline $2>\mathrm{MOH}+$ AspAsp $^{3-}+3 \mathrm{H}^{+} \rightarrow(>\mathrm{MO})_{2}$ AspAsp $+2 \mathrm{H}_{2} \mathrm{O}$ & - & 23.5 & 19.5 & 22.0 \\
\hline
\end{tabular}

${ }^{1}$ Electrostatic factor associated with the reaction. ${ }^{2}$ The mole fraction-based equilibrium constants as inputs in Visual MINTEQ. See Appendix A Table A3 presented by reference [20] for the correlations among different thermodynamic expressions for the surface complexation reactions.

In our previous ETLM study for Asp adsorption on goethite [20], we assumed innerand outer-sphere surface complexations using the $\beta-\mathrm{COO}^{-}$group (Figure $1 \mathrm{~b}$ ):

$$
\begin{gathered}
2>\mathrm{FeOH}+\mathrm{Asp}^{2-}+2 \mathrm{H}^{+} \rightarrow(>\mathrm{FeO})_{2} \mathrm{Asp}+2 \mathrm{H}_{2} \mathrm{O}, \\
2>\mathrm{FeOH}+\mathrm{Asp}^{2-}+3 \mathrm{H}^{+} \rightarrow\left(>\mathrm{FeOH}_{2}{ }^{+}\right)_{2} \mathrm{Asp}^{-},
\end{gathered}
$$

This model agreed with the following experimental observations: (1) the amount of Asp adsorption increased with the positive charge development on goethite by $\mathrm{pH}$ acidification, which indicates the electrostatic interaction to be an important factor; (2) no adsorption of glycine and glycylglycine occurred, which suggests a negligible contribution of the $\alpha$ $\mathrm{COO}^{-}$group to Asp adsorption; and (3) the same stoichiometries adequately represented AspGly adsorption, which supports Asp 'standing' geometry anchoring the $\beta-\mathrm{COO}^{-}$group rather than Asp 'lying down' conformation on the goethite surface. Similar to goethite, ferrihydrite, $\gamma$-alumina, and anatase possess net positive surface charges in neutral to acidic $\mathrm{pH}$ [27] (Figure A4). Since the four minerals exhibited similar $\mathrm{pH}$ and electrolyteconcentration dependences of Asp adsorption that were attributable to the electrostatic Asp-surface interaction (Figure 2), we applied the stoichiometries in Equations (1) and (2) to all the ETLM fittings.
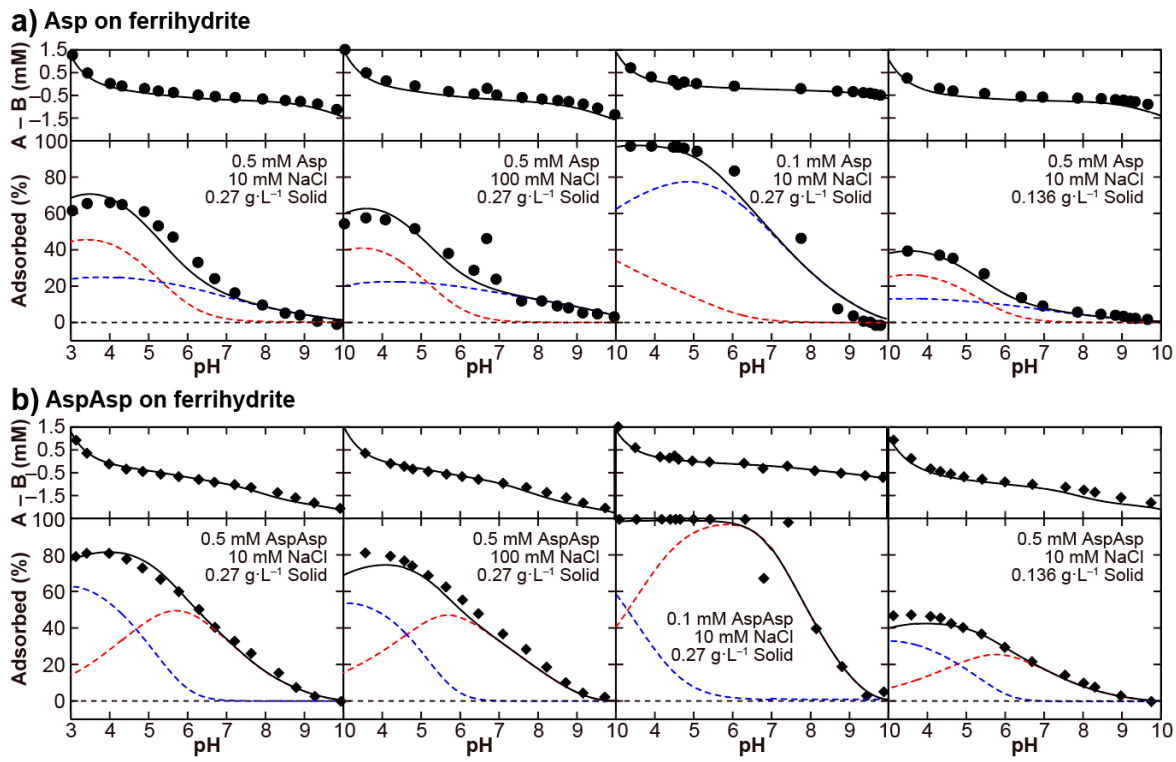

Figure 2. Cont. 
C) Asp on anatase

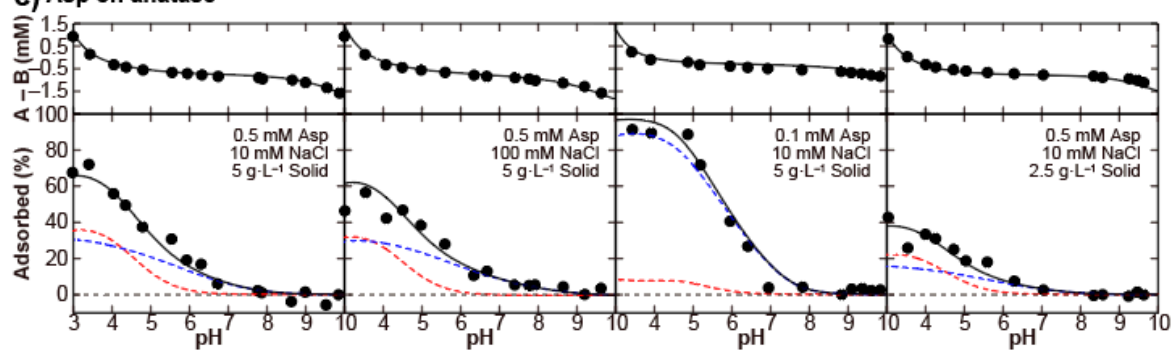

d) AspAsp on anatase

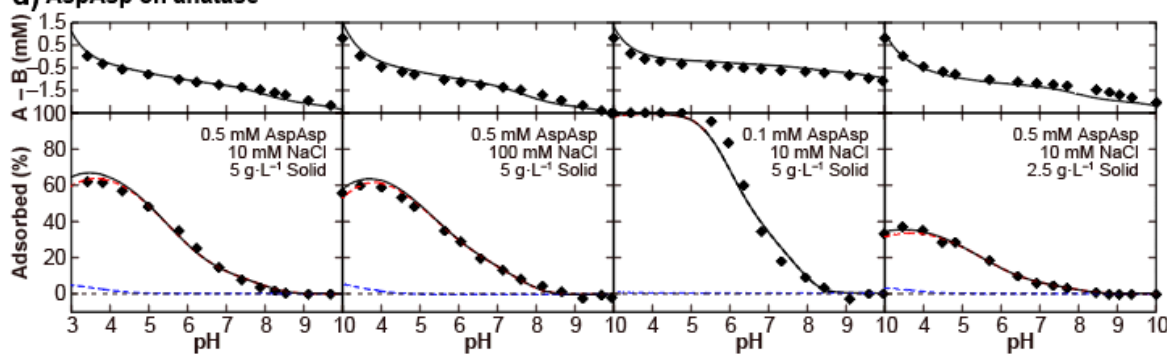

e) Asp on $\mathrm{V}$-alumina

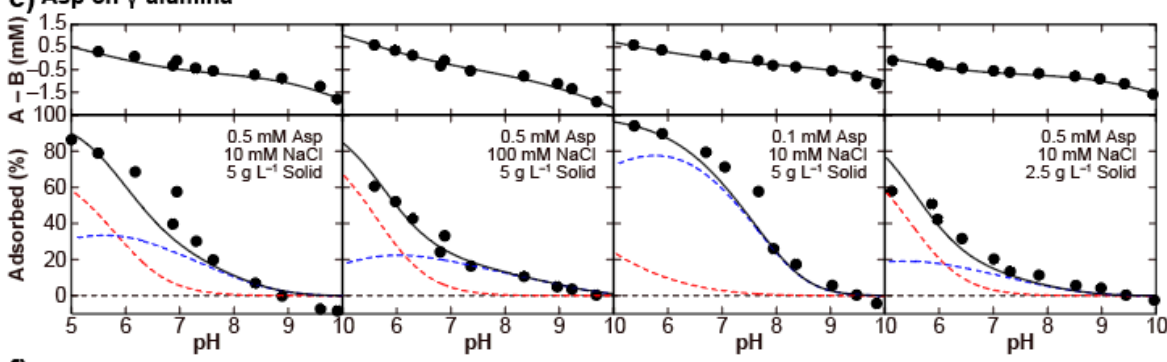

f) AspAsp on $y$-alumina

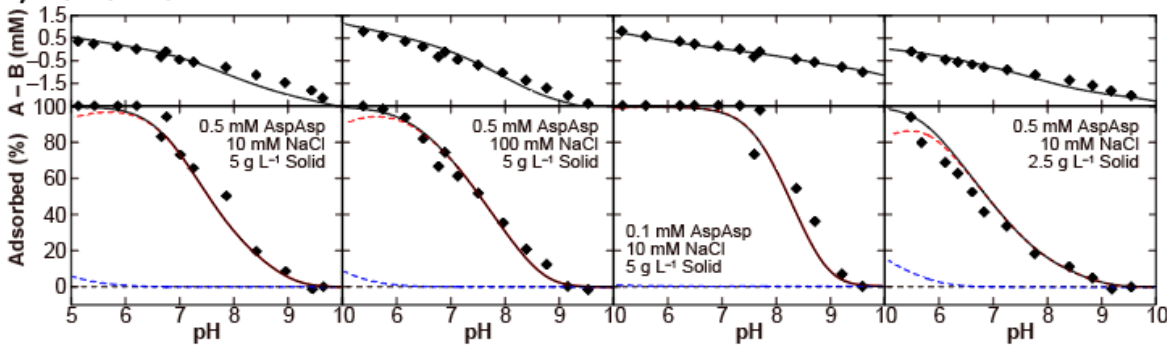

Figure 2. Percentages of the adsorbed Asp and AspAsp on ferrihydrite (a,b), anatase (c,d), and $\gamma$-alumina (e,f) at various $\mathrm{pH}$, the initial Asp (or AspAsp) concentration, $\mathrm{NaCl}$ concentration, and solid/water ratio are shown in the bottom sections, and the responses of $\mathrm{pH}$ to the addition of an acid $(\mathrm{A} ; \mathrm{HCl})$ or base $(\mathrm{B} ; \mathrm{NaOH})$ into the sample suspensions are presented in the top sections. Symbols represent the experimental data, and solid lines are the regression fits with the ETLM. Red and blue lines in the bottom sections show the contributions of the red- and blue-colored surface species depicted in Figure 1b,c to the total Asp or AspAsp adsorptions (black lines).

Our model is different from the ETLM description of Asp adsorption on rutile by Jonsson et al. [39], where the tetradentate-tetranuclear inner-sphere complex connecting the $\alpha$ - and $\beta-\mathrm{COO}^{-}$groups with four surface Ti atoms was assumed, with an outer-sphere complex, following the ATR-IR observation by ref. [49]. However, as mentioned above, such strong $\alpha-\mathrm{COO}^{-}$group-surface binding is unlikely because of the proximity of the $\alpha-\mathrm{NH}_{3}{ }^{+}$group. The IR absorption signals of the $\alpha$ - and $\beta-\mathrm{COO}^{-}$groups of Asp are strongly overlapping, making the unambiguous identification of the respective chemical states difficult. Further, the spectral distortion associated with the ATR technique [53-55] complicates the data interpretation. Different interpretations for Asp binding mode on $\mathrm{TiO}_{2}$ were proposed by ref. [49] and ref. [47] (Table A3), although their observed spectral profiles were similar to each other. From a modeling perspective, the adsorption data by Jonsson 
et al. [39] can be represented by Equations (1) and (2) (Figure A5a-d). Additionally, the two equations allow the simulation of the experimental data by ref. [44] for Asp adsorption on anatase (Figure A5e-g). In contrast, the application of the four surface-sites occupancy model [39] to our results requires surface-site densities of up to $5.7,2.0$, and $4.2 \mathrm{~nm}^{-2}$ on ferrihydrite, $\gamma$-alumina, and anatase, respectively. The value for ferrihydrite is much larger than the ferrihydrite site density available for the multidentate-multinuclear complexes estimated by ref. [56] $\left(2.8 \pm 0.6 \mathrm{~nm}^{-2}\right)$. Thus, although further investigations with advanced surface analytical techniques are required, we maintain our interpretation that Asp forms inner- and outer-sphere complexes on all the examined minerals via the $\beta-\mathrm{COO}^{-}$group (Figure 1b). Our model adequately represented the experimental Asp adsorption data at various $\mathrm{pH}$, the initial Asp concentration, $\mathrm{NaCl}$ concentration, and solid/water ratio (Figure 2a,c,e). Thus, the determined adsorption constants (Table 1) can be used to simulate the solid-liquid partitioning of Asp in a wide range of environmental conditions, from which the thermodynamic property of adsorbed Asp is calculable relative to the property of the dissolved counterpart (Figure 1a).

Similarly, for AspAsp, we applied the stoichiometries previously used for AspAsp adsorption on goethite [20] (Figure 1c):

$$
\begin{gathered}
2>\mathrm{FeOH}+\mathrm{AspAsp}^{3-}+2 \mathrm{H}^{+} \rightarrow(>\mathrm{FeO})_{2} \mathrm{AspAsp}^{-}+2 \mathrm{H}_{2} \mathrm{O}, \\
2>\mathrm{FeOH}+\mathrm{AspAsp}{ }^{3-}+3 \mathrm{H}^{+} \rightarrow(>\mathrm{FeO})_{2} \text { AspAsp }+2 \mathrm{H}_{2} \mathrm{O},
\end{gathered}
$$

Good ETLM fits were achieved in all the examined reaction conditions (Figure $2 b, d, f)$.

\subsection{Thermodynamic Prediction of Asp Dimerization at the Mineral-Water Interface}

Asp is one of the oldest biological components among the 20 coded protein amino acids [57-60]. Since numerous nonenzymatic processes are known to generate Asp [6,61], abiotically formed Asp is likely to have distributed widely on the primitive Earth, being transported through water circulation to various mineral-water interfaces. The same situation may be expected on Earth-like habitable bodies given the ubiquity of Asp in carbonaceous chondrites $[61,62]$.

To evaluate the Asp dimerization reactivity under interfacial conditions from a thermodynamic perspective, we computed the monomer-dimer equilibria of Asp on ferrihydrite, $\gamma$-alumina, and anatase with the ETLM parameters obtained in this study. The formation constants from $\mathrm{Asp}^{2-}$ of all the dissolved and adsorbed AspAsp species were calculated by setting the $\log \mathrm{K}$ value for the zwitterionic Asp dimerization in water (i.e., Asp ${ }^{ \pm}+\mathrm{Asp}^{ \pm} \rightarrow$ AspAsp ${ }^{ \pm}+\mathrm{H}_{2} \mathrm{O}$ ) to -3.0 [16] and by combining this value with the respective AspAsp protonation and adsorption constants (Table $\mathrm{A} 4$ ). The examined $\mathrm{pH}$ and $\mathrm{NaCl}$ concentrations were 3-10 (5-10 for $\gamma$-alumina) and 1-100 mM, respectively, corresponding to a range of natural waters in rivers, soil, terrestrial springs, saline lakes, and rainfall [63-67]. There is no definitive constraint on the $\alpha$-amino acid abundance in primitive environments. Thus, the Asp concentration was arbitrarily set to $0.01,0.1$, or $1 \mathrm{mM}$ to assess the influence of this parameter on the AspAsp/Asp equilibrium.

When no external Asp supply is assumed, the Asp concentration in the interfacial water decreases through Asp adsorption and dimerization, whereas the Asp concentration is maintained if a sustained flow of Asp-containing fluid is considered. Although both the 'closed' and 'open' systems are likely to exist in nature, we consider the latter case because calculations with fixed aqueous species concentrations give the mole fractions of the adsorbed species (and hence, the AspAsp/Asp ratio in the adsorbed state) independent of the amount and specific surface area of the mineral. Thus, the open system is beneficial for directly comparing the thermodynamic impacts per certain surface area of different minerals. In other words, this assumption can 'normalize' the availabilities of mineral surfaces that vary with environmental situations. In all the dimerization calculations described below, AspAsp was computed to be mostly adsorbing (>99.9\%) unless the Aspto-AspAsp conversion ratio was less than $0.1 \%$. Thus, the formation and accumulation of 
AspAsp are expected to occur only on the surface under a continuous Asp supply from an aqueous solution. Notice that the thermodynamic calculation is applicable to various environmental simulations. Owing to space limitations, we present some representative results in the parameter range specified above, and discuss the feasibility of abiotic Asp dimerization at the mineral-water interface.

Figure 3a shows the AspAsp/Asp ratios on ferrihydrite, $\gamma$-alumina, anatase, and goethite equilibrated with $0.1 \mathrm{mM}$ Asp in $1 \mathrm{mM} \mathrm{NaCl}$ solution. Ferrihydrite exhibited the strongest enhancement in the neutral to acidic $\mathrm{pH}$ region, leading to an AspAsp/Asp ratio up to $41 \%$, which was approximately $5 \times 10^{7}$ times higher than that attainable without mineral $\left(8.5 \times 10^{-6} \%\right.$ at $\left.\mathrm{pH} 4\right)$. Larger percentages of up to $53 \%$ were computed from $1 \mathrm{mM}$ Asp (Figure $3 b$ ), while higher $\mathrm{NaCl}$ concentrations suppressed the reaction (Figure 3c). Factors influencing the AspAsp/Asp ratio include the Asp concentration and AspAsp stability relative to Asp in the adsorbed state. Ferrihydrite adsorbed Asp and AspAsp with the highest surface densities among the four minerals (Figure A6a,d) and adsorbed AspAsp with a greater affinity than Asp (Figure A6). These surface properties make ferrihydrite the most effective promoter of Asp dimerization. Specifically, in equilibrium with $0.1 \mathrm{mM}$ Asp in $1 \mathrm{mM} \mathrm{NaCl}$ at $\mathrm{pH} 4,1.25$ Asp molecules per square nanometer of ferrihydrite were calculated (Figure 3b; the Asp-to-AspAsp conversion was not considered in this calculation). Taking a typical distance from a solid surface to the $\beta$-plane (5 $\AA$ [68]) into account, the Asp surface density corresponds to the interfacial concentration of $4.2 \mathrm{~mol} \cdot \mathrm{L}^{-1}$, which is $4.2 \times 10^{4}$ times larger than the bulk Asp concentration $(0.1 \mathrm{mM})$. Thus, the Asp concentration factor gives a $1.7 \times 10^{9}$ times enhancement of the equilibrium AspAsp/Asp ratio. Again, this simple calculation does not consider the adsorptive competition between Asp and AspAsp.

(a)

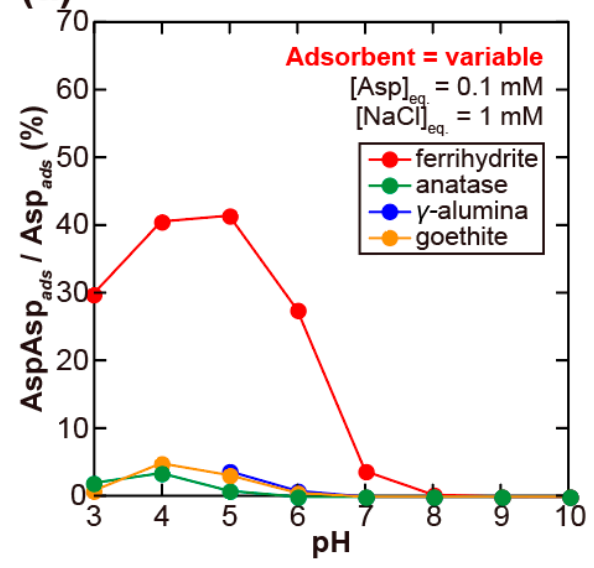

(b)

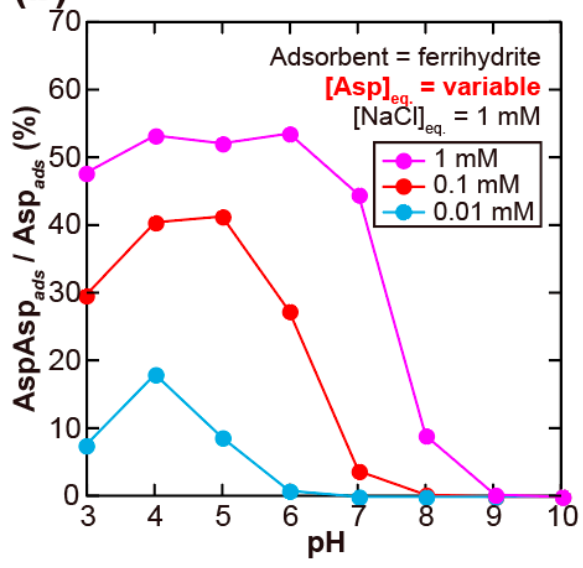

(c)

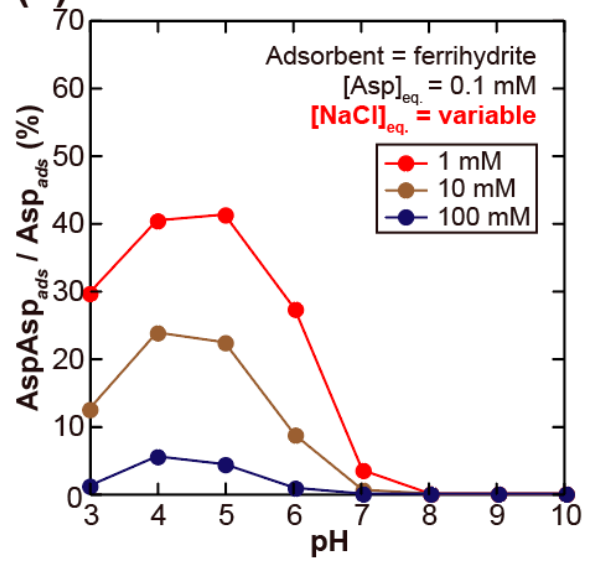

Figure 3. Thermodynamic prediction of the AspAsp/Asp molecular ratio in the adsorbed state. In (a), the ratio is calculated for the case of various mineral adsorbents at fixed equilibrium Asp and $\mathrm{NaCl}$ concentrations ( 0.1 and $1 \mathrm{mM}$, respectively), whereas the influences of the equilibrium Asp and $\mathrm{NaCl}$ concentrations are presented only for ferrihydrite in (b) and (c). Note that the results are independent on the solid/water ratio in the 'open' system examined here.

A drawback of ferrihydrite is its instability in water. In nature, ferrihydrite occurs in the early stage of weathering and gradually transforms into more stable forms, such as goethite and hematite, with reduced surface areas and lower adsorptivities [69]. Therefore, for the surface to promote Asp dimerization, the addition of crystallization inhibitors (e.g., silicate [70]) and/or improvement of the surface catalytic activity (e.g., doping of metals with different valence states) may be necessary. In our Asp adsorption experiments with ferrihydrite, no AspAsp was observed (detection limit: $\sim 0.001 \mathrm{mM}$ ) even after the basification of the sample suspensions to release adsorbed species.

Nonetheless, its excellent adsorptivity for AspAsp should have been advantageous for prebiotic Asp polymerization. Numerous abiotic mechanisms are known to polymerize 
amino acids [71-74]. Ferrihydrite likely trapped and concentrated the resultant AspAsp even from a dilute aqueous solution. If a ferrihydrite-coated sandstone with $10 \%$ porosity, which corresponds to the pore volume to mass ratio of $0.042 \mathrm{~L} \cdot \mathrm{kg}^{-1}$ [75], is considered, 0.1 $\mathrm{wt} \%$ of ferrihydrite enables the accumulation of $1.4 \mathrm{mmol}$ AspAsp per one-kilogram of sandstone from a $0.01 \mathrm{mM}$ AspAsp-containing solution at $\mathrm{pH} 4$ (background electrolyte: $1 \mathrm{mM} \mathrm{NaCl}$ ). The accumulated AspAsp will eventually be released through the aging of ferrihydrite, but its transportation with limited diffusion onto a catalytic surface may lead to the next stage of peptide bonding. AspAsp desorption is also caused by raising the $\mathrm{pH}$ and $\mathrm{NaCl}$ concentration (Figure $3 \mathrm{a}-\mathrm{c}$ ). Conversely, a $\mathrm{pH}$ increase induces ferrihydrite precipitation. Thus, the repeated cycles of Asp accumulation, desorption, and polymerization may have been possible through geochemical processes with fluctuating water flow, such as rainfall in dry environments and water discharge from terrestrial vent systems [76]. In dry conditions, ferrihydrite and the other three minerals catalyze peptide bond formation [77-81]. Thus, Asp might also have polymerized on a single mineral surface through wetting-drying cycles.

In brine environments (e.g., saline lakes and sea), the adsorption-derived shift of the monomer-dimer equilibrium is limited (Figure 3c). However, because AspAsp adsorption is less dependent on $\mathrm{NaCl}$ concentration than Asp adsorption (Figure A6c,f), brine environments may be advantageous for selectively accumulating AspAsp from aqueous Asp-AspAsp mixtures. For ferrihydrite, for example, the adsorptive competition of an equimolar concentration of Asp and AspAsp (0.01 mM) results in a surface AspAsp/Asp ratio of 1.37 in the presence of $1 \mathrm{mM} \mathrm{NaCl}$ at $\mathrm{pH} 4$ (Asp dimerization is not considered). The ratio increases to 1.54 when $100 \mathrm{mM} \mathrm{NaCl}$ is used as the background electrolyte. Thus, mineral surfaces can selectively capture AspAsp relative to Asp in both on-land and undersea settings, increasing the favorability of Asp peptide elongation.

\section{Summary and Future Research Directions}

In this article, we demonstrated a thermodynamic approach to evaluate the impact of mineral surfaces on amino acid polymerization using ferrihydrite, anatase, and $\gamma$ alumina as the minerals for Asp adsorption and dimerization. This approach enables us to theoretically screen wide environmental settings, thereby narrowing down the parameter space to be examined in-depth (e.g., by laboratory simulations) for determining suitable geochemical situations for abiotic peptide synthesis. The obtained adsorption constants are useful not only for calculating the amino acid/peptide equilibria in the adsorbed state but also for simulating the selection and accumulation of the respective compounds from an aqueous solution.

An important next step is determining the key interfacial mechanisms controlling Asp and AspAsp adsorptions, thereby enabling the prediction of the adsorption constants for any mineral-Asp (or AspAsp) combinations based on a limited number of known constants. There is a predictive scheme for simple inorganic ions (e.g., $\mathrm{Na}^{+}$and $\mathrm{Cl}^{-}$) [32,82], but its application to our results did not provide a theoretically explainable outcome (data not shown), possibly because of the presence of several functional groups in Asp and AspAsp structures. Our computational results are, in some cases, not immediately understandable; for example, denser AspAsp adsorption was calculated on goethite than on anatase under the same reaction conditions (Figure A6d), while the opposite relationship was obtained for that of Asp (Figure A6a). Since there are tendencies that anatase dehydrates chemisorbed molecules whereas adsorbates on goethite retain their solvation shells [68], functional groups not directly involved in AspAsp adsorption (e.g., $\mathrm{NH}_{3}{ }^{+}$group) might have a stronger influence on the net binding strength on anatase than that on goethite. For the AspAsp-anatase system, in fact, the contribution of the net-neutral surface species $\left((>\mathrm{MO})_{2} \mathrm{AspAsp}\right)$ was calculated to be minor relative to the negatively charged species $\left((>\mathrm{MO})_{2} \mathrm{AspAsp}^{-}\right)$(Figure 2f), which was a cause of the relatively low affinity of anatase for AspAsp adsorption (Figure A6a). The role of each functional group should be elucidated to clarify AspAsp-surface interactions. A survey of sulfide minerals is also meaningful 
because sulfide-rich hydrothermal vent environments are among the most plausible settings for life's origin on Earth, and possibly so on Earth-like habitable bodies [83-89]. Further experimental and theoretical investigations on the topics mentioned above will lead to a better understanding of the suitable mineral-water interfacial conditions for abiotic peptide synthesis crucial for the emergence of life.

Author Contributions: N.K. conceived the entire project, and K.N. performed the adsorption experiments. W.T. analyzed the adsorbent samples. The ETLM analysis of the adsorption data and thermodynamic calculations were conducted by N.K. All authors have read and agreed to the published version of the manuscript.

Funding: This research was funded by JSPS KAKENHI, grant number 18H04456 and 20H00209.

Institutional Review Board Statement: Not applicable.

Informed Consent Statement: Not applicable.

Data Availability Statement: The data presented in this study are available on request from the corresponding author.

Acknowledgments: We thank Maki Akimoto for her administrative support at ELSI, Tokyo Tech.

Conflicts of Interest: The authors declare no conflict of interest. The funder had no role in the design of the study; in the collection, analyses, or interpretation of data; in the writing of the manuscript, or in the decision to publish the results.

\section{Appendix A}

Table A1. Protonation constants ( $\log K)$ of Asp [38] and AspAsp [39].

\begin{tabular}{cccc}
\hline Reaction & logK & Reaction & $\operatorname{logK}$ \\
\hline $\mathrm{Asp}^{2-}+\mathrm{H}^{+} \rightarrow \mathrm{Asp}^{-}$ & 9.66 & AspAsp $^{3-}+\mathrm{H}^{+} \rightarrow \mathrm{AspAsp}^{2-}$ & 8.11 \\
$\mathrm{Asp}^{2-}+2 \mathrm{H}^{+} \rightarrow \mathrm{Asp}^{ \pm}$ & 13.37 & AspAsp $^{3-}+2 \mathrm{H}^{+} \rightarrow \mathrm{AspAsp}^{-}$ & 12.50 \\
$\mathrm{Asp}^{2-}+3 \mathrm{H}^{+} \rightarrow \mathrm{Asp}^{+}$ & 15.32 & AspAsp $^{3-}+3 \mathrm{H}^{+} \rightarrow \mathrm{AspAsp}^{ \pm}$ & 15.87 \\
- & - & AspAsp $^{3-}+4 \mathrm{H}^{+} \rightarrow \mathrm{AspAsp}^{+}$ & 18.45 \\
\hline
\end{tabular}

Table A2. The specific surface area $\left(\mathrm{A}_{\mathrm{s}}\right)$, the surface site density $\left(\mathrm{N}_{\mathrm{s}}\right)$, solid concentration $(\mathrm{Cs})$, and inner- and outer-layer capacitances $\left(C_{1}\right.$ and $\left.C_{2}\right)$ of ferrihydrite, anatase and $\gamma$-alumina.

\begin{tabular}{ccccc}
\hline Oxide & $\mathbf{A}_{\mathbf{s}}\left(\mathbf{m}^{\mathbf{2}} \cdot \mathbf{g}^{-\mathbf{1}}\right)$ & $\mathbf{N}_{\mathbf{s}}\left(\mathbf{n m} \mathbf{m}^{-\mathbf{1}}\right)$ & $\mathbf{C}_{\mathbf{s}}\left(\mathbf{g} \cdot \mathbf{L}^{-\mathbf{1}}\right)$ & $\mathbf{C}_{\mathbf{1}}=\mathbf{C}_{\mathbf{2}} \cdot\left(\boldsymbol{\mu} \mathbf{F} \cdot \mathbf{c m}^{-\mathbf{1}}\right)$ \\
\hline Ferrihydrite & 600 & 3.8 & 0.136 or 0.27 & 130 \\
anatase & 164 & 3 & 2.5 or 5 & 131 \\
$\gamma$-alumina & 49.4 & 8 & 2.5 or 5 & 99 \\
\hline
\end{tabular}


Table A3. Summary of the reported spectroscopic and computational interpretations of the Asp binding structure on oxide minerals.

\begin{tabular}{|c|c|c|c|c|c|c|}
\hline Oxide & Method ${ }^{1}$ & Asp & $\mathrm{pH}$ & Electrolyte & Asp Adsorption Mode ${ }^{2}$ & Ref. \\
\hline goethite & $\begin{array}{l}\text { ATR-IR \& } \\
\text { DFT }\end{array}$ & 1,5, or $10 \mathrm{mM}$ & 3,6, or 11 & $\begin{array}{l}0.01,0.1, \text { or } \\
0.2 \mathrm{M} \mathrm{NaCl}\end{array}$ & $\begin{array}{l}\text { At } \mathrm{pH} \text { 3: The BB ISC binding the } \alpha- \\
\text { and } \gamma-\mathrm{COO}^{-} \text {groups with two } \\
\text { surface Fe atoms } \\
\text { At } \mathrm{pH} \text { 6: Primarily an OSC with a } \\
\text { minor contribution of the IS } \\
\text { complex as observed at } \mathrm{pH} 3 \\
\text { At } \mathrm{pH} \text { 11: The HB between the } \mathrm{NH}_{2} \\
\text { group and surface hydroxyl groups }\end{array}$ & [90] \\
\hline magnetite & MD & $0.5 \mathrm{mM}$ & 3.5 & $0.1 \mathrm{M} \mathrm{NaCl}$ & $\begin{array}{l}\text { The electrostatic interaction } \\
\text { involving monodentate } \alpha-\mathrm{COO}^{-}-\mathrm{Fe} \\
\text { and } \gamma-\mathrm{COO}^{-}-\mathrm{Fe} \text { bindings and a } \\
\text { tridentate } \mathrm{NH}_{3}^{+}-\mathrm{O} \text { binding. }\end{array}$ & [91] \\
\hline$\gamma-\mathrm{Al}_{2} \mathrm{O}_{3}$ & ATR-IR & 3 or $7 \mathrm{mM}$ & $2.8,3.8$, or 6.0 & $0.1 \mathrm{M} \mathrm{NaCl}$ & $\begin{array}{l}\text { The BB ISC binding the } \gamma-\mathrm{COO}^{-} \\
\text {group with two surface } \mathrm{Al} \text { atoms } \\
\text { and the TT ISC binding the } \alpha \text { - and } \\
\gamma-\mathrm{COO}^{-} \text {groups with four } \mathrm{Al} \text { atoms }\end{array}$ & [92] \\
\hline anatase & XPS & $\begin{array}{c}0.4,1.2, \text { or } \\
1.5 \mu \mathrm{mol} \mathrm{m}^{-2}\end{array}$ & 4 & - & An ISC involving the $\mathrm{NH}_{2}$ group & [44] \\
\hline anatase & DFT & - & - & - & $\begin{array}{l}\text { An OSC involving the side-chain } \\
\mathrm{CH}_{2} \text { group }\end{array}$ & [46] \\
\hline anatase & MOPS & - & - & - & $\begin{array}{l}\text { The } \mathrm{HB} \text { between the } \mathrm{NH}_{3}{ }^{+} \text {group } \\
\text { and the surface oxygen }\end{array}$ & [45] \\
\hline rutile & $\begin{array}{l}\text { ATR-IR \& } \\
\text { QCC }\end{array}$ & $\begin{array}{l}0.1,1, \text { or } \\
4.4 \mathrm{mM}\end{array}$ & 3 or 6 & $0.1 \mathrm{M} \mathrm{NaCl}$ & $\begin{array}{l}\text { An OSC involving the } \alpha-\text { and } \\
\gamma-\mathrm{COO}^{-} \text {groups }\end{array}$ & [47] \\
\hline rutile & DFT & - & - & - & $\begin{array}{l}\text { A complex involving the } \alpha-\mathrm{COO}^{-} \\
\text {and } \mathrm{NH}_{3}{ }^{+} \text {groups (the binding } \\
\text { mode (ISC or OSC) depends on the } \\
\text { initial setting for water molecules) }\end{array}$ & [48] \\
\hline $\mathrm{TiO}_{2}$ & ATR-IR & $0.3 \mathrm{mM}$ & $1.5-10.8$ & $\begin{array}{c}5 \mathrm{mM} \\
\mathrm{N}\left(\mathrm{CH}_{3}\right)_{4} \mathrm{ClO}_{4}\end{array}$ & $\begin{array}{l}\text { The TT ISC binding the } \alpha \text { - and } \\
\gamma \text {-COO } \\
\text { Ti atoms }\end{array}$ & [49] \\
\hline $\mathrm{TiO}_{2}$ & SFG & $0.1-5 \mathrm{mg} \mathrm{ml}^{-1}$ & 3 & $0.02 \mathrm{M} \mathrm{NaCl}$ & $\begin{array}{l}\text { An ISC involving a monodentate } \\
\mathrm{COO}^{-}-\mathrm{Ti} \text { binding and a } \mathrm{HB} \\
\text { involving another } \mathrm{COO}^{-} \text {group }\end{array}$ & [50] \\
\hline $\mathrm{TiO}_{2}$ & NMR \& MD & $10 \mathrm{mM}$ & 7 & $\begin{array}{c}20 \mathrm{mM} \\
\text { phosphate }\end{array}$ & $\begin{array}{l}\text { An OSC involving the } \alpha-\mathrm{COO}^{-} \text {and } \\
\mathrm{NH}_{3}{ }^{+} \text {groups }\end{array}$ & [51] \\
\hline
\end{tabular}

${ }^{1}$ Abbreviations: ATR-IR: attenuated total reflection infrared spectroscopy, DFT: density functional theory calculation, MD: molecular dynamics simulation, MOPS: modeling within the MOPS algorithm [93], QCC: quantum chemical calculation, SFG: sum frequency generation vibrational spectroscopy. ${ }^{2}$ Abbreviations: ISC: inner-sphere complex, OSC: outer-sphere complex, HB: hydrogen bonding, BB: bidentate-binuclear, TT: tetradentate-tetranuclear.

Table A4. Formation constants from $\mathrm{Asp}^{2-}$ of the dissolved and adsorbed AspAsp species used for the equilibrium calculation of Asp dimerization in the presence of ferrihydrite (Fer.), anatase (Ana.), $\gamma$-alumina ( $\gamma$-Al.), or Goethite (Goe.) (Figure 3).

\begin{tabular}{|c|c|c|c|c|}
\hline \multirow{2}{*}{ Reaction } & \multicolumn{4}{|c|}{$\log K$} \\
\hline & Fer. & Ana. & $\gamma$-Al. & Goe. $^{2}$ \\
\hline $2 \mathrm{Asp}^{2-}+\mathrm{H}^{+} \rightarrow \mathrm{AspAsp}^{3-}$ & \multicolumn{4}{|c|}{7.9} \\
\hline $2 \mathrm{Asp}^{2-}+2 \mathrm{H}^{+} \rightarrow \mathrm{AspAsp}^{2-}$ & \multicolumn{4}{|c|}{16.0} \\
\hline $2 \mathrm{Asp}^{2-}+3 \mathrm{H}^{+} \rightarrow \mathrm{AspAsp}^{-}$ & \multicolumn{4}{|c|}{20.4} \\
\hline $2 \mathrm{Asp}^{2-}+4 \mathrm{H}^{+} \rightarrow \mathrm{AspAsp}^{ \pm}$ & \multicolumn{4}{|c|}{23.7} \\
\hline $2 \mathrm{Asp}^{2-}+5 \mathrm{H}^{+} \rightarrow \mathrm{AspAsp}^{+}$ & \multicolumn{4}{|c|}{26.3} \\
\hline $2>\mathrm{MOH}+2 \mathrm{Asp}^{2-}+3 \mathrm{H}^{+} \rightarrow(>\mathrm{MO})_{2} \mathrm{AspAsp}^{-}+3 \mathrm{H}_{2} \mathrm{O}$ & $29.3^{1}$ & $26.9^{1}$ & $27.4^{1}$ & $27.7^{1}$ \\
\hline $2>\mathrm{MOH}+2 \mathrm{Asp}^{2-}+4 \mathrm{H}^{+} \rightarrow(>\mathrm{MO})_{2}$ AspAsp $+3 \mathrm{H}_{2} \mathrm{O}$ & $31.4^{1}$ & $27.4^{1}$ & $29.9^{1}$ & $31.9^{1}$ \\
\hline
\end{tabular}

${ }^{1}$ Mole fraction-based equilibrium constants. ${ }^{2}$ Taken from ref. [20]. 
(a)

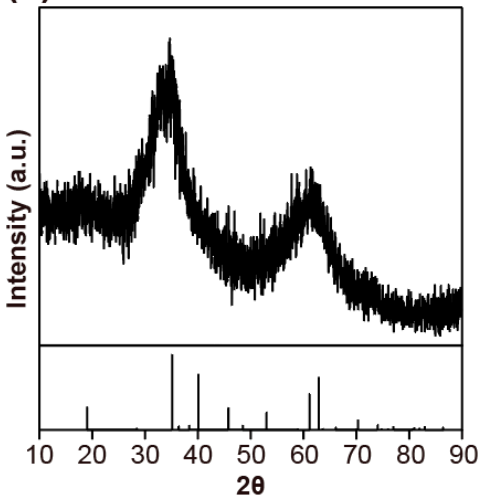

(b)

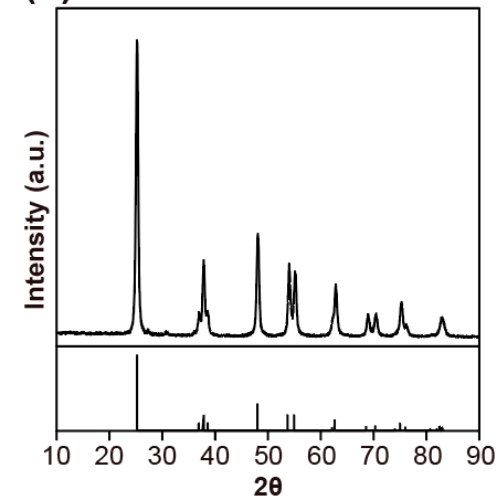

(c)

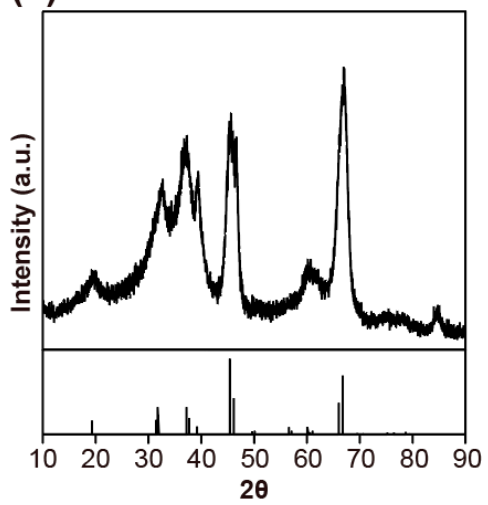

Figure A1. XRD patterns of (a) ferrihydrite, (b) anatase, and (c) $\gamma$-alumina obtained using an X-ray diffractometer (MiniFlex 600; Rigaku, Tokyo, Japan) with $\mathrm{Cu} \mathrm{K} \alpha$ radiation. All runs were conducted with $0.02^{\circ} 2 \theta$ step and the scan rate of $1^{\circ} \cdot \mathrm{min}^{-1}$. Reference patterns shown in the bottom sections were taken from Inorganic Crystal Structure Database for ferrihydrite (ICSD 56287) and $\gamma$-alumina (ICSD 99836), and the reference pattern of anatase was taken from International Centre for Diffraction Data (ICDD PDF 01-071-1166).

(a)

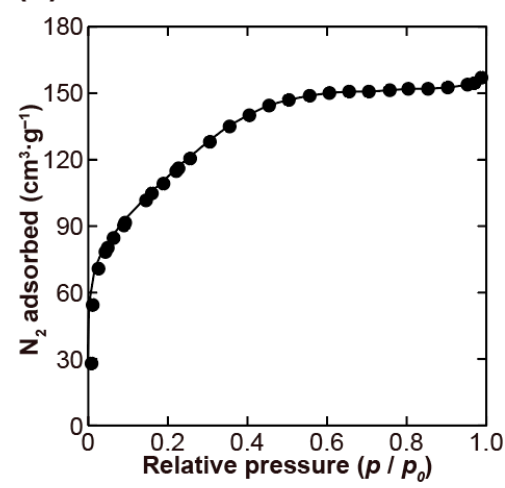

(b)

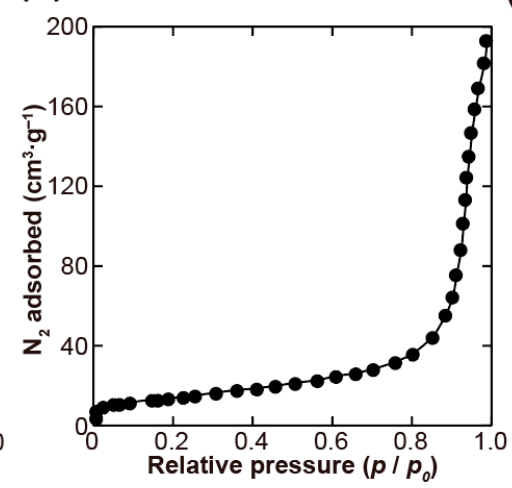

(c)

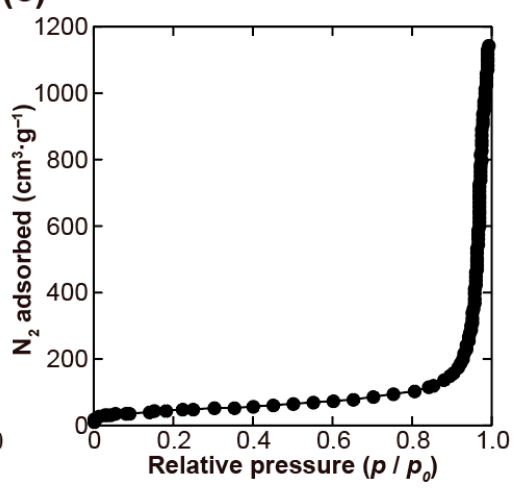

Figure A2. $\mathrm{N}_{2}$ adsorption isotherms at the $\mathrm{N}_{2}$ boiling temperature $(77 \mathrm{~K})$ on (a) ferrihydrite, (b) anatase, and (c) $\gamma$-alumina measured with a BET surface area analyzer (BELSORB mini II; MicrotracBEL, Osaka, Japan). Prior to the measurements, ferrihydrite was dried under vacuum for $48 \mathrm{~h}$ at $20^{\circ} \mathrm{C}$, and anatase and $\gamma$-alumina were dried under vacuum for $3 \mathrm{~h}$ at $150{ }^{\circ} \mathrm{C}$.

(a)

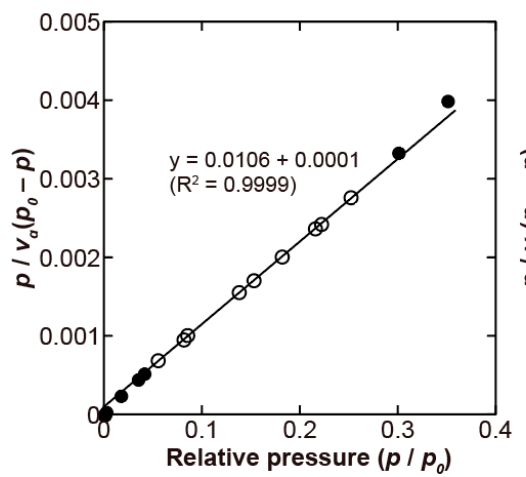

(b)

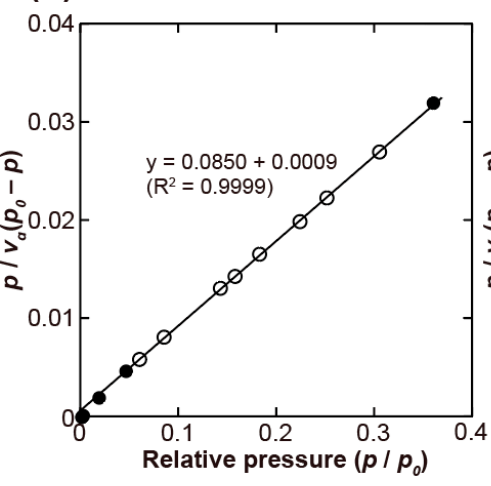

(c)

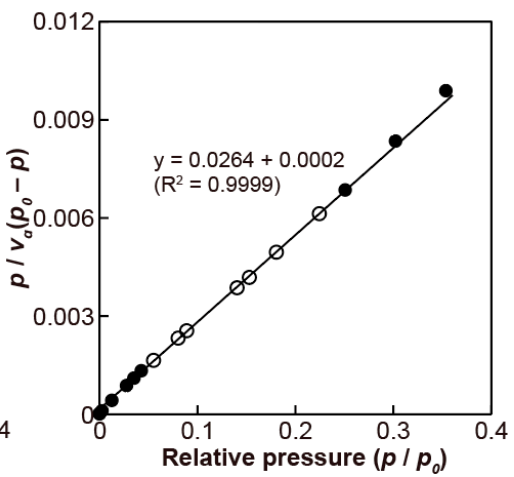

Figure A3. BET plots for (a) ferrihydrite, (b) anatase, and (c) $\gamma$-alumina calculated from the $\mathrm{N}_{2}$ adsorption isotherms presented in Figure A2. The regression lines were obtained using the data shown with open cycle symbols. 
(a)

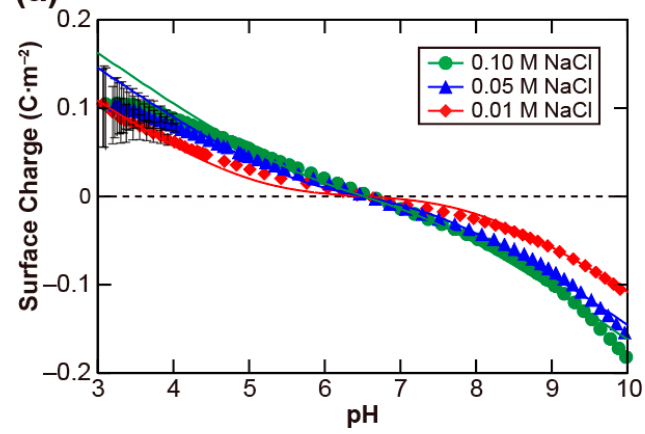

(b)

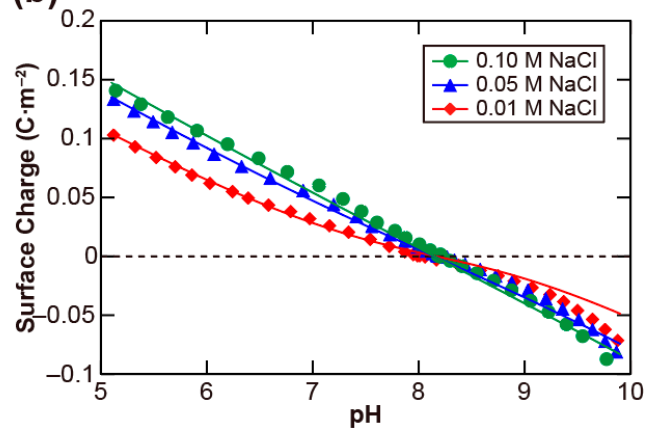

Figure A4. Surface charge densities of (a) anatase and (b) $\gamma$-alumina as a function of pH in 10, 50, and $100 \mathrm{mM} \mathrm{NaCl}$. Symbols denote the experimental acid-base titration data, whereas solid lines represent the ETLM calculation with the parameters presented in Table 1.
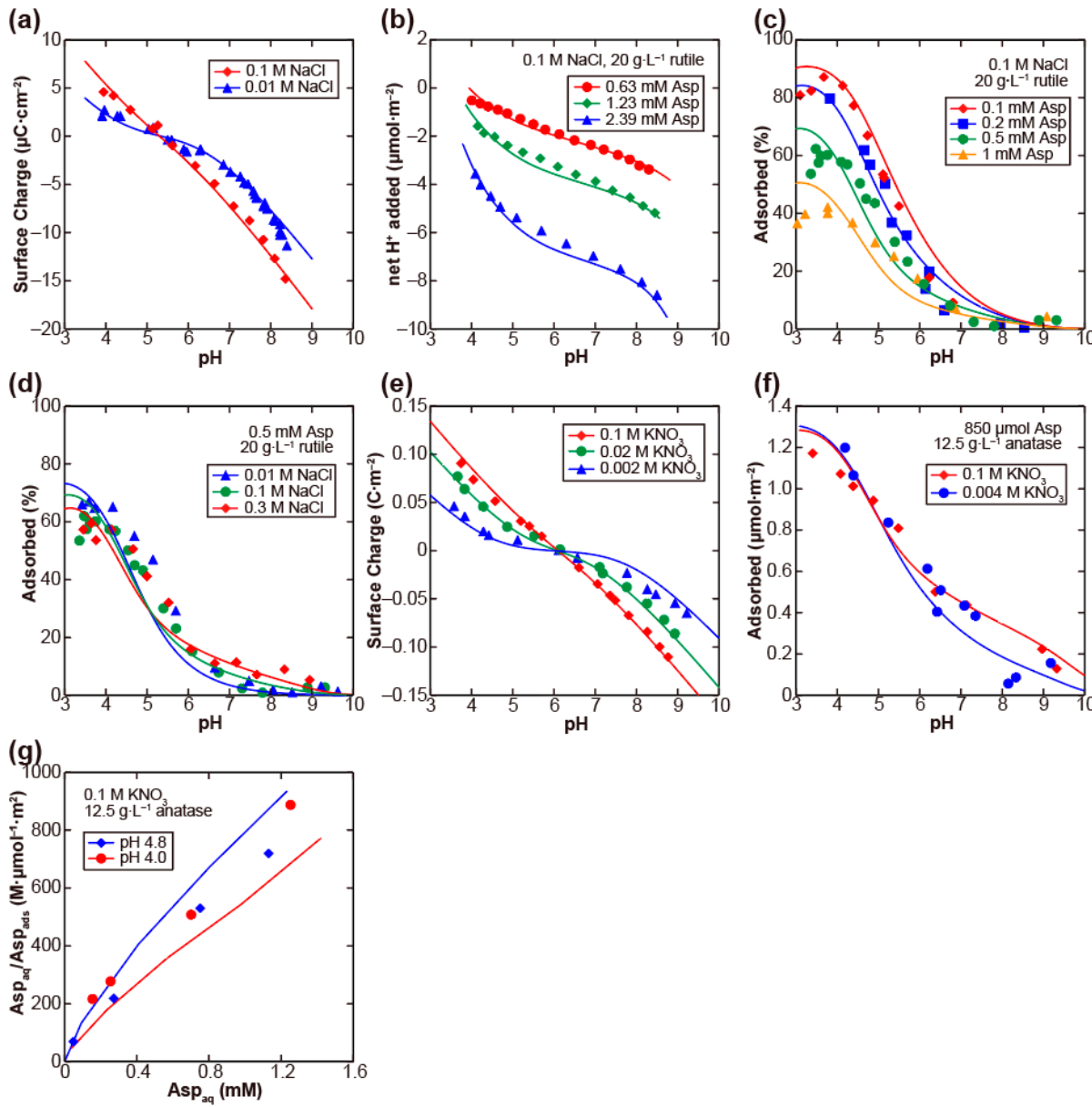

Figure A5. ETLM fittings (lines) of the reported experimental data (symbols) for Asp adsorption on rutile [43] (a-d) and on anatase [44] (e-g). The ETLM parameters used for these fittings are: $A_{s}=18.1 \mathrm{~m}^{2} \cdot \mathrm{g}^{-1}, \mathrm{~N}_{\mathrm{s}},=3 \mathrm{~nm}^{-2}, \mathrm{C}_{1}\left(=\mathrm{C}_{2}\right)=1.2 \mathrm{~F} \cdot \mathrm{m}^{2}$, $\log \mathrm{K}_{1},=2.52, \log \mathrm{K}_{2},=-8.23, \log \mathrm{K}_{\mathrm{Na}^{+}}=-5.6, \log \mathrm{K}_{\mathrm{Cl}^{-}}=5.0, \log \mathrm{K}_{(\mathrm{FeO})_{2} \mathrm{Asp}}=17.0$, and $\log \mathrm{K}_{\left(\mathrm{FeOH}_{2}^{+}\right)_{2} \mathrm{Asp}^{-}}=24.0$ for the Asp-rutile system, and $\mathrm{A}_{\mathrm{s}}=47 \mathrm{~m}^{2} \cdot \mathrm{g}^{-1}, \mathrm{~N}_{\mathrm{s}},=3 \mathrm{~nm}^{-2}, \mathrm{C}_{1}\left(=\mathrm{C}_{2}\right)=1.08 \mathrm{~F} \cdot \mathrm{m}^{2}, \log \mathrm{K}_{1},=2.7, \log \mathrm{K}_{2},=-9.3, \log \mathrm{K}_{\mathrm{K}^{+}}=-6.4$, $\log \mathrm{K}_{\mathrm{NO}_{3}^{-}}=5.8, \log \mathrm{K}_{(\mathrm{FeO})_{2} \mathrm{Asp}}=17.4$, and $\log \mathrm{K}_{\left(\mathrm{FeOH}_{2}^{+}\right)_{2} \mathrm{Asp}^{-}}=27.3$ for the Asp-anatase system. The values of $\mathrm{N}_{\mathrm{s}}, \mathrm{C}_{1}\left(=\mathrm{C}_{2}\right)$,

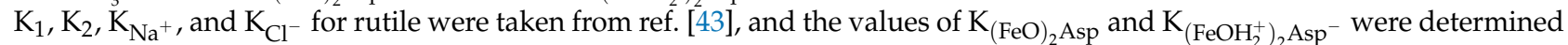
by the ETLM fitting of the experimental Asp adsorption data $(\mathbf{b}-\mathbf{d})$. The values of $\mathrm{N}_{\mathrm{s}}, \mathrm{C}_{1}\left(=\mathrm{C}_{2}\right), \mathrm{K}_{1}$ and $\mathrm{K}_{2}$ for anatase were taken from ref. [32], and the values of $\mathrm{K}_{\mathrm{K}^{+}}$and $\mathrm{K}_{\mathrm{NO}_{3}^{-}}$were estimated from the ETLM fitting of the anatase surface charge data (e). The values of $\mathrm{K}_{(\mathrm{FeO})_{2} \mathrm{Asp}}$ and $\mathrm{K}_{\left(\mathrm{FeOH}_{2}^{+}\right)_{2} \mathrm{Asp}}$ - were then determined based on the Asp adsorption data (f,g). All $\log \mathrm{K}$ values are presented as the mole fraction-based equilibrium constants. 
(a)

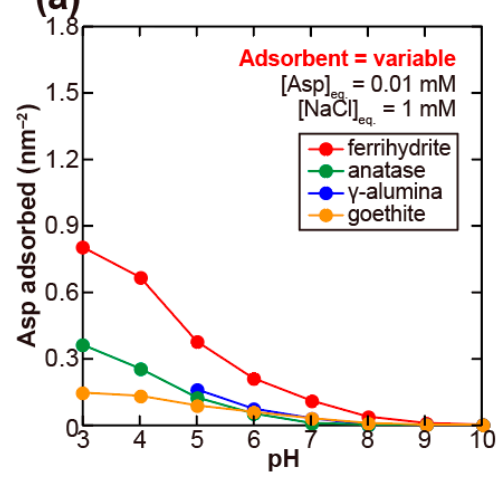

(d)

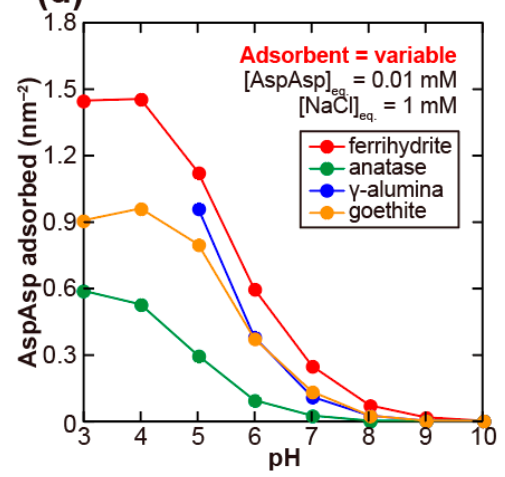

(b)

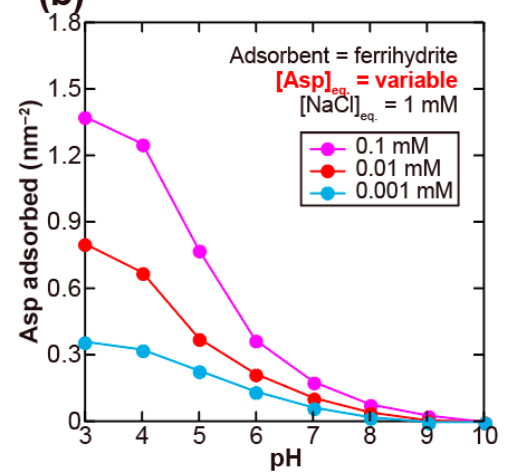

(e)

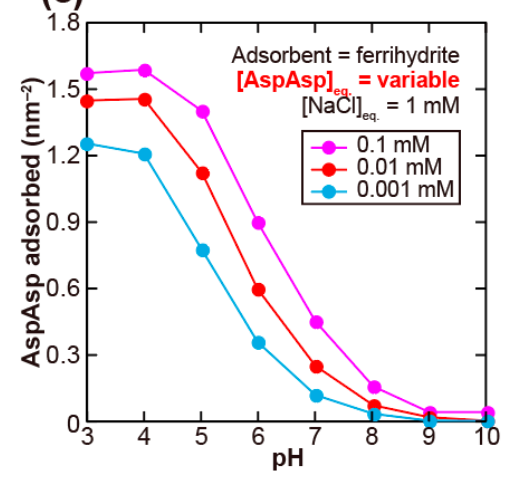

(c)

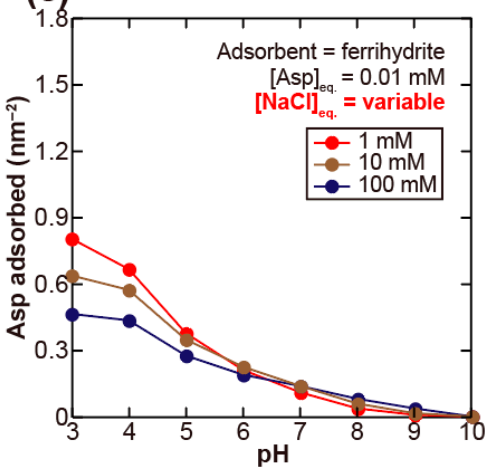

(f)

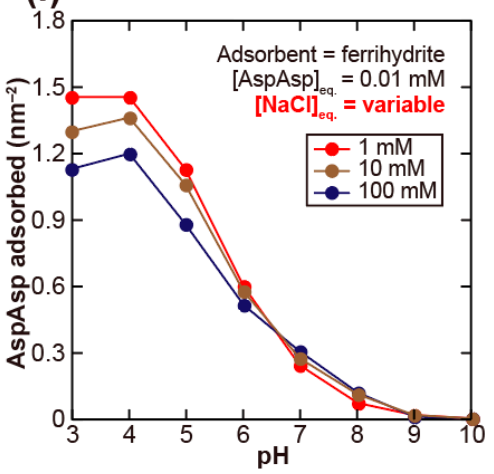

Figure A6. Thermodynamic prediction of the surface densities (the number of molecules per a square nanometer) of adsorbed Asp (a-c) and AspAsp (d-f). Interconversion between Asp and AspAsp is not considered in this calculation. In (a) and (d), the densities on various mineral adsorbents were calculated at fixed equilibrium Asp (or AspAsp) and $\mathrm{NaCl}$ concentrations ( 0.01 and $1 \mathrm{mM}$, respectively), whereas the influences of the equilibrium Asp (or AspAsp) and $\mathrm{NaCl}$ concentrations are presented only for ferrihydrite in (b), (c), (e), and (c). Note that the results are independent on the solid/water ratio in the 'open' system examined here.

\section{References}

1. Kaltenegger, L. How to characterize habitable worlds and signs of life. Annu. Rev. Astron. Astrophys. 2017, 55, 433-485. [CrossRef]

2. Fujii, Y.; Angerhausen, D.; Deitrick, R.; Domagal-Goldman, S.; Grenfell, J.L.; Hori, Y.; Kane, S.R.; Palle, E.; Rauer, H.; Siegler, N.; et al. Exoplanet biosingnatures: Observational prospects. Astrobiology 2018, 18, 739-777. [CrossRef]

3. Barge, L.M.; Flores, E.; Baum, M.M.; VanderVelde, D.G.; Russell, M.J. Redox and pH gradients drive amino acid synthesis in iron oxyhydroxide mineral systems. Proc. Natl. Acad. Sci. USA 2019, 116, 4828-4833. [CrossRef] [PubMed]

4. Kimura, J.; Kitadai, N. Polymerization of building blocks of life on Europa and other icy moons. Astrobiology 2015, 15, 430-441. [CrossRef]

5. Takahagi, W.; Seo, K.; Shibuya, T.; Takano, Y.; Fujishima, K.; Saitoh, M.; Shimamura, S.; Matsui, Y.; Tomita, M.; Takai, K. Peptide synthesis under the alkaline hydrothermal conditions on Enceladus. ACS Earth Space Chem. 2019, 3, 11. [CrossRef]

6. Kitadai, N.; Maruyama, S. Origins of building blocks of life: A review. Geosci. Front. 2018, 9, 1117-1153. [CrossRef]

7. Burton, A.S.; Stern, J.C.; Elsila, J.E.; Glavin, D.P.; Dworkin, J.P. Understanding prebiotic chemistry through the analysis of extraterrestrial amino acids and nucleotides in meteorites. Chem. Soc. Rev. 2012, 41, 5459-5472. [CrossRef]

8. Pizzarello, S.; Cooper, G.W.; Flynn, G.J. The nature and distribution of the organic material in carbonaceous chondrites and interplanetary duct particles. In Meteorites and the Early Solar System II; Lauretta, D.S., McSween, H.Y., Jr., Eds.; University of Arizona Press: Tucson, AZ, USA, 2006; pp. 625-651.

9. Suwannachot, Y.; Rode, B.M. Mutual amino acid catalysis in salt-induced peptide formation supports this mechanism's role in prebiotic peptide evolution. Orig. Life Evol. Biosph. 1999, 29, 463-471. [CrossRef]

10. Pizzarello, S.; Weber, A.L. Prebiotic amino acids as asymmetric catalysts. Science 2004, 303, 1151. [CrossRef]

11. Cleaves II, H.J.; Scott, A.M.; Hill, F.C.; Leszczynski, J.; Sahai, N.; Hazen, R. Mineral-organic interfacial processes: Potential roles in the origin of life. Chem. Soc. Rev. 2012, 41, 5502-5525. [CrossRef]

12. Erastova, V.; Degiacomi, M.T.; Fraser, D.G.; Greenwell, H.C. Mineral surface chemistry control for origin of prebiotic peptides. Nat. Commun. 2017, 8, 2033. [CrossRef] [PubMed]

13. Cleaves, H.J.; Aubrey, A.D.; Bada, J.L. An evaluation of the critical parameters for abiotic peptide synthesis in submarine hydrothermal systems. Orig. Life Evol. Biosph. 2009, 39, 109-126. [CrossRef] 
14. Krissansen-Totton, J.; Arney, G.N.; Catling, D.C. Constraining the climate and ocean pH of the early Earth with a geological carbon cycle model. Proc. Natl. Acad. Sci. USA 2018, 115, 4105-4110. [CrossRef]

15. Schoonen, M.; Smirnov, A.; Cohn, C. A perspective on the role of minerals in prebiotic synthesis. Ambio 2004, 33, 539-551. [CrossRef]

16. Kitadai, N. Thermodynamic prediction of glycine polymerization as a function of temperature and pH consistent with experimentally obtained results. J. Mol. Evol. 2014, 78, 171-187. [CrossRef] [PubMed]

17. Kitadai, N. Energetics of amino acid synthesis in alkaline hydrothermal environments. Orig. Life Evol. Biosph. 2015, 45, 377-409. [CrossRef] [PubMed]

18. Kitadai, N. Predicting thermodynamic behaviors of non-protein amino acids as a function of temperature and pH. Orig. Life Evol. Biosph. 2016, 46, 3-18. [CrossRef] [PubMed]

19. Kitadai, N.; Nishiuchi, K.; Nishii, A.; Fukushi, K. Amorphous silica-promoted lysine dimerization: A thermodynamic prediction. Orig. Life Evol. Biosph. 2018, 48, 23-34. [CrossRef] [PubMed]

20. Kitadai, N.; Nishiuchi, K. Thermodynamic impact of mineral surfaces on amino acid polymerization: Aspartate dimerization on goethite. Astrobiology 2019, 19, 1363-1376. [CrossRef]

21. Kitadai, N.; Yokoyama, T.; Nakashima, S. ATR-IR spectroscopic study of L-lysine adsorption on amorphous silica. J. Colloid Interf. Sci. 2009, 329, 31-37. [CrossRef]

22. Kitadai, N. Dissolved divalent metal and $\mathrm{pH}$ effects on amino acid polymerization: A thermodynamic evaluation. Orig. Life Evol. Biosph. 2017, 47, 13-37. [CrossRef]

23. Cudennec, Y.; Lecerf, A. The transformation of ferrihydrite into goethite or hematite, revisited. J. Solid State Chem. 2006, 179, 716-722. [CrossRef]

24. Kim, J.D.; Yee, N.; Nanda, V.; Falkowski, P.G. Anoxic photochemical oxidation of siderite generates molecular hydrogen and iron oxides. Proc. Natl. Acad. Sci. USA 2013, 110, 10073-10077. [CrossRef]

25. Zaia, D.A.M.; Zaia, C.T.B.V. A few experimental suggestions using minerals to obtain peptides with a high concentration of L-amino acids and protein amino acids. Symmetry 2020, 12, 2046. [CrossRef]

26. Davis, J.A.; Leckie, J.O. Surface ionization and complexation at the oxide/water interface. II. Surface properties of amorphous iron oxyhydroxide and adsorption of metal ions. J. Colloid Interf. Sci. 1978, 67, 90-107. [CrossRef]

27. Fukushi, K.; Aoyama, K.; Yang, C.; Kitadai, N.; Nakashima, S. Surface complexation modeling for sulfate adsorption on ferrihydrite consistent with in situ infrared spectroscopic observations. Appl. Geochem. 2013, 36, 92-103. [CrossRef]

28. Kitadai, N.; Nishiuchi, K.; Tanaka, M. A comprehensive predictive model for sulfate adsorption on oxide minerals. Geochim. Cosmochim. Acta 2018, 238, 150-168. [CrossRef]

29. Mendez, J.C.; Hiemstra, T. Surface area of ferrihydrite consistently related to primary surface charge, ion pair formation, and specific ion adsorption. Chem. Geol. 2020, 532, 119304. [CrossRef]

30. Michel, F.M.; Ehm, L.; Antao, S.M.; Lee, P.L.; Chupas, P.J.; Liu, G.; Strongin, D.R.; Schoonen, M.A.A.; Phillips, B.L.; Parise, J.B. The structure of ferrihydrite, a nanocrystalline material. Science 2007, 316, 1726-1729. [CrossRef]

31. Fukushi, K.; Tsukimura, K.; Yamada, H. Surface acidity of amorphous aluminum hydroxide. Acta Geol. Sin. 2006, 80, $206-211$. [CrossRef]

32. Sverjensky, D.A. Prediction of surface charge on oxides in salt solutions: Revisions for 1:1 ( $\left.\mathrm{M}^{+} \mathrm{L}^{-}\right)$electrolytes. Geochim. Cosmochim. Acta 2005, 69, 225-257. [CrossRef]

33. Sverjensky, D.A.; Fukushi, K. Anion adsorption on oxide surfaces: Inclusion of the water dipole in modeling the electrostatics of ligand exchange. Environ. Sci. Technol. 2006, 40, 263-271. [CrossRef] [PubMed]

34. Sahai, N.; Sverjensky, D.A. GEOSURF: A computer program for modeling adsorption on mineral surfaces from aqueous solution. Comput. Geosci. 1998, 24, 853-873. [CrossRef]

35. Schecher, W.D.; McAvoy, D.C. MINTEQL+: A Chemical Equilibrium Modeling System, Ver. 5.0; Environmental Research Software: Hallowell, ME, USA, 2016.

36. Parkhurst, D.L.; Appelo, C.A.J. Description of Input and Examples for PHREEQC ver. 3-A Computer Program for Speciation, BatchReaction, One-Dimensional Transport, and Inverse Geochemical Calculations; U.S. Geological Survey: Reston, VA, USA, 2013.

37. Gustafsson, J.P. Visual MINTEQ, Ver. 3.1; Royal Institute of Technology: Stockholm, Sweden, 2016.

38. Martell, A.E.; Smith, R.M.; Motekaitis, R.J. NIST critically selected stability constants of metal complexes. In NIST Standard Reference Database Number 46, Version 8.0; NIST: Gaithersburg, MD, USA, 2004.

39. Kallay, C.; Varnagy, K.; Micera, G.; Sanna, D.; Sovago, I. Copper (II) complexes of oligopeptides containing aspartyl and glutamyl residues. Potentiometric and spectroscopic studies. J. Inorg. Biochem. 2005, 99, 1514-1525. [CrossRef]

40. Shock, E.L.; Sassani, D.C.; Willis, M.; Sverjensky, D.A. Inorganic species in geologic fluids: Correlations among standard molal thermodynamic properties of aqueous ions and hydroxide complexes. Geochim. Cosmochim. Acta 1997, 61, 907-950. [CrossRef]

41. Sverjensky, D.A.; Shock, E.L.; Helgeson, H.C. Prediction of the thermodynamic properties of aqueous metal complexes to $1000{ }^{\circ} \mathrm{C}$ and $5 \mathrm{~kb}$. Geochim. Cosmochim. Acta 1997, 61, 1359-1412. [CrossRef]

42. Pokrovskii, V.A. Calculation of the standard partial molal thermodynamic properties and dissociation constants of aqueous $\mathrm{HCl}^{0}$ and $\mathrm{HBr}^{0}$ at temperatures to $1000{ }^{\circ} \mathrm{C}$ and pressures to 5 kbar. Geochim. Cosmochim. Acta 1999, 63, 1107-1115. [CrossRef]

43. Jonsson, C.M.; Jonsson, C.L.; Estrada, C.; Sverjensky, D.A.; Cleaves, H.J., II; Hazen, R.M. Adsorption of L-aspartate to rutile $\left(\alpha-\mathrm{TiO}_{2}\right)$ : Experimental and theoretical surface complexation studies. Geochim. Cosmochim. Acta 2010, 74, 2356-2367. [CrossRef] 
44. Giacomelli, C.E.; Avena, M.J.; De Pauli, C.P. Aspartic acid adsorption onto $\mathrm{TiO}_{2}$ particles surface. Experimental data and model calculations. Langmuir 1995, 11, 3483-3490. [CrossRef]

45. Shchelokov, A.; Palko, N.; Potemkin, V.; Grishina, M.; Morozov, R.; Korina, E.; Vchaev, D.; Krivtsov, I.; Bol'shakov, O. Adsorption of native amino acids on nanocrystalline $\mathrm{TiO}_{2}$ : Physical chemistry, QSPR, and theoretical modeling. Langmuir 2019, 35, 538-550. [CrossRef]

46. Liu, L.; Li, K.; Chen, X.; Liang, X.; Zheng, Y.; Li, L. Amino acid adsorption on anatase (101) surface a vacuum and aqueous solution: A density functional study. J. Mol. Model. 2018, 24, 107. [CrossRef]

47. Parikh, S.; Kubicki, J.D.; Jonsson, C.M.; Jonsson, C.L.; Hazen, R.M.; Sverjensky, D.A.; Sparks, D.L. Evaluating glutamate and aspartate binding mechanisms to rutile $\left(\alpha-\mathrm{TiO}_{2}\right)$ via ATR-FTIR spectroscopy and quantum chemical calculations. Langmuir 2011, 27, 1778-1787. [CrossRef]

48. Guo, Y.; Lu, X.; Zhang, H.; Weng, J.; Watari, F.; Leng, Y. DFT study of the adsorption of aspartic acid on pure, N-doped, and Ca-doped rutile (110) surfaces. J. Phys. Chem. C 2011, 115, 18572-18581. [CrossRef]

49. Roddick-Lanzilotta, A.D.; McQuillan, A.J. An in situ infrared spectroscopic study of glutamic acid and of aspartic acid adsorption on $\mathrm{TiO}_{2}$ : Implications for the biocompatibility of titanium. J. Colloid Interf. Sci. 2000, 227, 48-54. [CrossRef]

50. Paszti, Z.; Guczi, L. Amino acid adsorption on hydrophilic $\mathrm{TiO}_{2}$ : A sum frequency generation vibrational spectroscopy study. Vib. Spectrosc. 2009, 50, 48-56. [CrossRef]

51. Xue, M.; Sampath, J.; Gebhart, R.N.; Haugen, H.J.; Lyngstadaas, S.P.; Pfaendtner, J.; Drobny, G. Studies of dynamic binding of amino acids to $\mathrm{TiO}_{2}$ nanoparticle surfaces by solution NMR and molecular dynamics simulations. Langmuir 2020, 36, 10341-10350. [CrossRef]

52. Thomas, A.G.; Syres, K.L. Adsorption of organic molecules on rutile $\mathrm{TiO}_{2}$ and anatase $\mathrm{TiO}_{2}$ single crystal surfaces. Chem. Soc. Rev. 2012, 41, 4207-4217. [CrossRef]

53. Kataoka, Y.; Kitadai, N.; Hisatomi, O.; Nakashima, S. Hydrogen bonding natures of water molecules in aqueous solutions of glycerol by attenuated total reflection (ATR) infrared spectroscopy. Appl. Spectrosc. 2011, 65, 436-441. [CrossRef] [PubMed]

54. Kitadai, N.; Yokoyama, T.; Nakashima, S. Temperature dependence of molecular structure of dissolved glycine as revealed by ATR-IR spectroscopy. J. Mol. Struct. 2010, 981, 179-186. [CrossRef]

55. Kitadai, N.; Sawai, T.; Tonoue, R.; Nakashima, S.; Katsura, M.; Fukushi, K. Effects of ions on the OH stretching band of water as revealed by ATR-IR spectroscopy. J. Sol. Chem. 2014, 43, 1055-1077. [CrossRef]

56. Hiemstra, T.; Zhao, W. Reactivity of ferrihydrite and ferritin in relation to surface structure, size, and nanoparticle formation studied for phosphate and arsenate. Environ. Sci. Nano 2016, 3, 1265-1279. [CrossRef]

57. Trifonov, E.N. Consensus temporal order of amino acids and evolution of the triple code. Gene 2000, 261, 139-151. [CrossRef]

58. Higgs, P.G.; Pudritz, R.E. A thermodynamic basis for prebiotic amino acid synthesis and the nature of the first genetic code. Astrobiology 2009, 9, 483-490. [CrossRef]

59. Van der Gulik, P.; Massar, S.; Gilis, D.; Buhrman, H.; Rooman, M. The first peptides: The evolutionary transition between prebiotic amino acids and early proteins. J. Theor. Biol. 2009, 261, 531-539. [CrossRef]

60. Ikehara, K. Possible steps to the emergence of life: The [GADV]-protein world hypothesis. Chem. Record 2005, 5, 107-118. [CrossRef]

61. Zaia, D.A.M.; Zaia, C.T.B.V.; De Santana, H. Which amino acids should be used in prebiotic chemistry studies? Orig. Life Evol. Biosph. 2008, 38, 469-488. [CrossRef]

62. Glavin, D.P.; Callahan, M.P.; Dworkin, J.P.; Elsila, J.E. The effects of parent body processes on amino acids in carbonaceous chondrites. Meteorit. Planet. Sci. 2011, 45, 1948-1972. [CrossRef]

63. Aoi, Y.; Fukushi, K.; Itono, T.; Kitadai, N.; Kashiwaya, K.; Yamada, H.; Hatta, T.; Manpuku, Y. Distribution and mineralogy of radioactive $\mathrm{Cs}$ in reservoir sediment contaminated by the Fukushima nuclear accident. J. Miner. Petrol. Sci. 2014, $109,23-27$. [CrossRef]

64. Suda, K.; Ueno, Y.; Yoshizaki, M.; Nakamura, H.; Kurokawa, K.; Nishiyama, E.; Yoshino, K.; Hongoh, Y.; Kawachi, K.; Omori, S.; et al. Origin of methane in serpentinite-hosted hydrothermal systems: The $\mathrm{CH}_{4}-\mathrm{H}_{2}-\mathrm{H}_{2} \mathrm{O}$ hydrogen isotope systematics of the Hakuba Happo hot spring. Earth Planet. Sci. Lett. 2014, 386, 112-125. [CrossRef]

65. Hao, J.; Sverjensky, D.A.; Hazen, R.M. A model for late Archean chemical weathering and world average river water. Earth Planet. Sci. Lett. 2017, 457, 191-203. [CrossRef]

66. Sekine, Y.; Kitajima, T.; Fukushi, K.; Gankhurel, B.; Tsetsgee, S.; Davaasuren, D.; Matsumiya, H.; Chida, T.; Nakamura, M.; Hasebe, N. Hydrogeochemical study on closed-basin lakes in cold and semi-arid climates of the valley of the Gobi lakes, Mongolia: Implications for hydrology and water chemistry of paleolakes on Mars. Minerals 2020, 10, 792. [CrossRef]

67. Fukushi, K.; Imai, E.; Sekine, Y.; Kitajima, T.; Gankhurel, B.; Davaasuren, D.; Hasebe, N. In situ formation of monohydrocalcite in alkaline saline lakes of the valley of Gobi lakes: Prediction for $\mathrm{Mg}, \mathrm{Ca}$, and total dissolved carbonate concentrations in Enceladus' Ocean and alkaline-carbonate Ocean worlds. Minerals 2020, 10, 669. [CrossRef]

68. Sverjensky, D.A. Interpretation and prediction of triple-layer model capacitances and the structure of the oxide-electrolyte-water interface. Geochim. Cosmochim. Acta 2001, 65, 3643-3655. [CrossRef]

69. Guo, H.; Barnard, A.S. Naturally occurring iron oxide nanoparticles: Morphology, surface chemistry and environmental stability. J. Mater. Chem. A 2013, 1, 27-42. [CrossRef] 
70. Cornell, R.M.; Giovanoli, R.; Schindler, P.W. Effect of silicate species on the transformation of ferrihydrite into goethite and hematite in alkaline media. Clays Clay Miner. 1987, 35, 21-28. [CrossRef]

71. Canavelli, P.; Islam, S.; Powner, M.W. Peptide ligation by chemoselective aminonitrile coupling in water. Nature 2019, 571, 546-571. [CrossRef] [PubMed]

72. Huber, C.; Wächtersäuser, G. Peptides by activation of amino acids with $\mathrm{CO}$ on $(\mathrm{Ni}, \mathrm{Fe}) \mathrm{S}$ surfaces: Implications for the origin of life. Science 1998, 291, 670-672. [CrossRef]

73. Kitadai, N.; Yokoyama, T.; Nakashima, S. Hydration-dehydration interactions between glycine and anhydrous salts: Implications for chemical evolution of life. Geochim. Cosmochim. Acta 2011, 75, 6285-6299. [CrossRef]

74. Kitadai, N.; Ooishi, H.; Umemoto, K.; Usui, T.; Fukushi, K.; Nakashima, S. Glycine polymerization on oxide minerals. Orig. Life Evol. Biosph. 2017, 47, 123-143. [CrossRef]

75. Nishiyama, N.; Yokoyama, T. Does the reactive surface area of sandstone depend on water saturation?-The role of reactivetransport in water film. Geochim. Cosmochim. Acta 2013, 122, 153-169. [CrossRef]

76. Mulkidjanian, A.Y.; Bychkov, A.Y.; Dibrova, D.V.; Galperin, M.Y.; Koonin, E.V. Origin of first cells at terrestrial, anoxic geothermal fields. Proc. Natl. Acad. Sci. USA 2012, 109, E821-E830. [CrossRef] [PubMed]

77. Matrajt, G.; Blanot, D. Properties of synthetic ferrihydrite as an amino acid adsorbent and a promoter of peptide bond formation. Amino Acids 2004, 26, 153-158. [CrossRef] [PubMed]

78. Shanker, U.; Bhushan, B.; Bhattacharjee, G.; Kamaluddin. Oligomerization of glycine and alanine catalyzed by iron oxides: Implications for prebiotic chemistry. Orig. Life Evol. Biosph. 2012, 42, 31-45. [CrossRef] [PubMed]

79. Leyton, P.; Saladino, R.; Crestini, C.; Campos-Vallette, M.; Paipa, C.; Berrios, A.; Fuentes, S.; Zarate, R.A. Influence of TiO 2 on prebiotic thermal synthesis of the Gly-Gln polymer. Amino Acids 2012, 42, 2079-2088. [CrossRef]

80. Jaber, M.; Spadavecchia, J.; Bazzi, H.; Georgelin, T.; Costa-Torro, F.; Lambert, J.F. Non-biological selectivity in amino acids polymerization on $\mathrm{TiO}_{2}$ nanoparticles. Amino Acids 2013, 45, 403-406. [CrossRef]

81. Martra, G.; Deiana, C.; Sakhno, Y.; Barberis, I.; Fabbiani, M.; Pazzi, M.; Vincenti, M. The formation and self-assembly of long prebiotic oligomers produced by the condensation of unactivated amino acids on oxide surfaces. Angezw. Chem. Int. Ed. 2014, 53, 4671-4674. [CrossRef] [PubMed]

82. Sverjensky, D.A. Physical surface-complexation models for sorption at the mineral-water interface. Nature 1993, 364, 776-780. [CrossRef]

83. Russell, M.J.; Barge, L.M.; Bharita, R.; Bocanegra, D.; Bracher, P.J.; Branscomb, E.; Kidd, R.; McGlynn, S.; Meier, D.H.; Nitschke, W.; et al. The drive to life on wet and icy worlds. Astrobiology 2014, 14, 308-343. [CrossRef]

84. Kitadai, N.; Kameya, M.; Fujishima, K. Origin of the reductive tricarboxylic acid (rTCA) cycle-type $\mathrm{CO}_{2}$ fixation: A perspective. Life 2017, 7, 39. [CrossRef]

85. Kitadai, N.; Nakamura, R.; Yamamoto, M.; Takai, K.; Li, Y.; Yamaguchi, A.; Gilbert, A.; Ueno, Y.; Yoshida, N.; Oono, Y. Geo-electrochemical CO production: Implications for the autotrophic origin of life. Sci. Adv. 2018, 4, eaao7265. [CrossRef]

86. Kitadai, N.; Nakamura, R.; Yamamoto, M.; Takai, K.; Yoshida, N.; Oono, Y. Metals likely promoted protometabolism in early ocean alkaline hydrothermal systems. Sci. Adv. 2019, 5, eaav7848. [CrossRef] [PubMed]

87. Li, Y.; Kitadai, N.; Nakamura, R. Chemical diversity of metal sulfide minerals and its implications for the origin of life. Life 2018, 8, 46. [CrossRef] [PubMed]

88. Nakashima, S.; Kebukawa, Y.; Kitadai, N.; Igisu, M.; Matsuoka, N. Geochemistry and the origin of life: From extraterrestrial processes, chemical evolution on Earth, fossilized life's records, to natures of the extant life. Life 2018, 8, 39. [CrossRef] [PubMed]

89. Sakata, K.; Kitadai, N.; Yokoyama, T. Effects of $\mathrm{pH}$ on dimerization rate of glycine: Evaluation of favorable environmental conditions for chemical evolution of life. Geochim. Cosmochim. Acta 2010, 74, 6841-6851. [CrossRef]

90. Yang, Y.; Wang, S.; Xu, Y.; Zheng, B.; Liu, J. Molecular-scale study of aspartate adsorption on goethite and competition with phosphate. Environ. Sci. Technol. 2016, 50, 2938-2945. [CrossRef]

91. Burger, A.; Magdans, U.; Gies, H. Adsorption of amino acids on the mangentite-(111)-surface: A force field study. J. Mol. Model. 2013, 19, 851-857. [CrossRef] [PubMed]

92. Greiner, E.; Kumar, K.; Sumit, M.; Giuffre, A.; Zhao, W.; Pedersen, J.; Sahai, N. Adsorption of L-glutamic acid and L-aspartic acid to $\gamma-\mathrm{Al}_{2} \mathrm{O}_{3}$. Geochim. Cosmochim. Acta 2014, 133, 142-155. [CrossRef]

93. Grishina, M.A.; Bartashevich, E.V.; Potemkin, V.A.; Belik, A.V. Genetic algorithm for predicting structures and properties of molecular aggregates in organic substances. J. Struct. Chem. 2002, 43, 1040-1044. [CrossRef] 